Prepared in cooperation with the Bureau of Reclamation

\title{
Water-Quality Data from Upper Klamath and Agency Lakes, Oregon, 2007-08
}

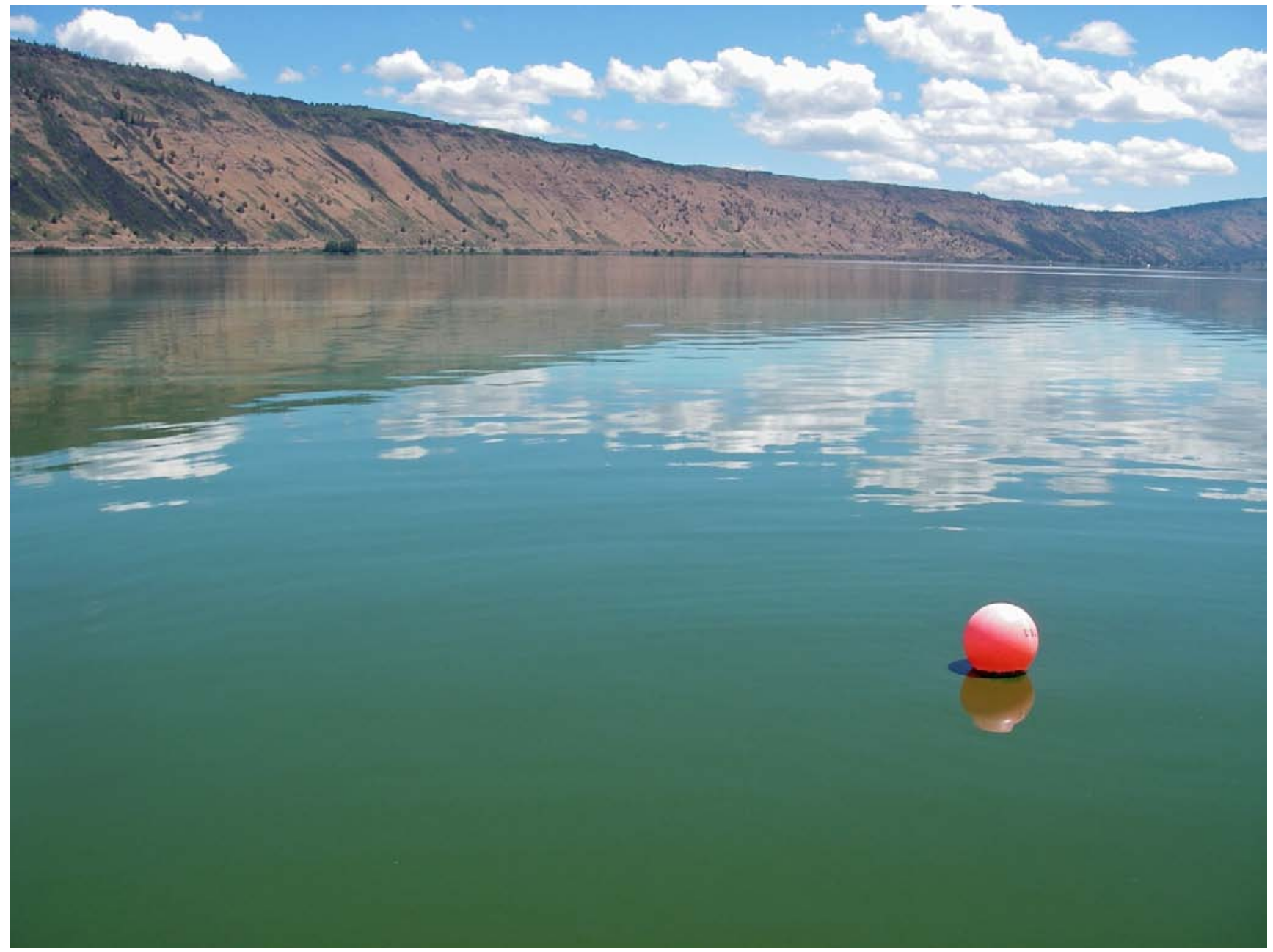

Open-File Report 2010-1073

U.S. Department of the Interior U.S. Geological Survey 
Front cover: Upper Klamath Lake in the vicinity of the Midlake monitoring site, looking east. (Photograph by Mary Lindenberg, USGS, summer 2007.)

Back cover: Aphanizomenon flos-aquae bloom at the Middle of Trench site. (Photograph by Kristofor Kannarr, USGS, summer 2008.) 


\section{Water-Quality Data from Upper Klamath and Agency Lakes, Oregon, 2007-08}

By Kristofor E. Kannarr, Dwight Q. Tanner, Mary K. Lindenberg, and Tamara M. Wood

Prepared in cooperation with the Bureau of Reclamation

Open-File Report 2010-1073

U.S. Department of the Interior

U.S. Geological Survey 


\section{U.S. Department of the Interior KEN SALAZAR, Secretary}

\section{U.S. Geological Survey Marcia K. McNutt, Director}

U.S. Geological Survey, Reston, Virginia: 2010

For more information on the USGS-the Federal source for science about the Earth, its natural and living resources, natural hazards, and the environment, visit http://www.usgs.gov or call 1-888-ASK-USGS.

For an overview of USGS information products, including maps, imagery, and publications, visit http://www.usgs.gov/pubprod

To order this and other USGS information products, visit http://store.usgs.gov

Suggested citation:

Kannarr, K.E., Tanner, D.Q., Lindenberg, M.K., and Wood, T.M., 2010, Water-quality data from Upper Klamath and Agency Lakes, Oregon, 2007-08: U.S. Geological Survey Open-File Report 2010-1073, 28 p.

Any use of trade, firm, or product names is for descriptive purposes only and does not imply endorsement by the U.S. Government

Although this report is in the public domain, permission must be secured from the individual copyright owners to reproduce any copyrighted material contained within this report. 


\section{Contents}

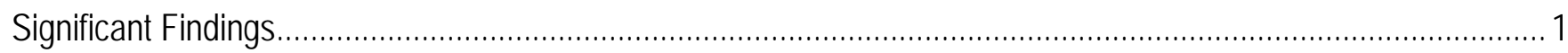

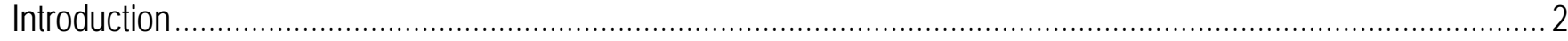

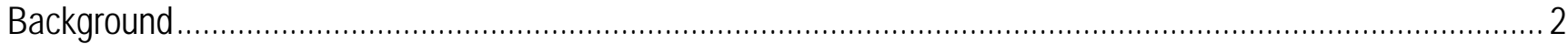

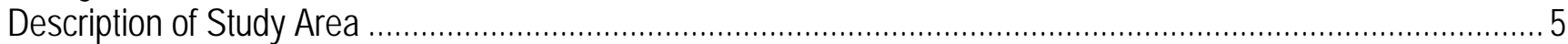

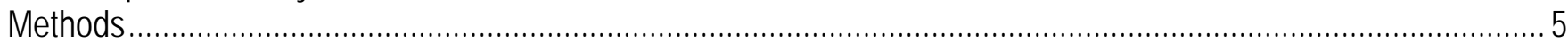

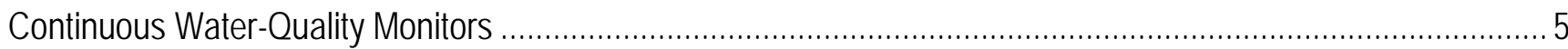

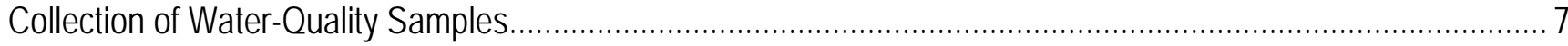

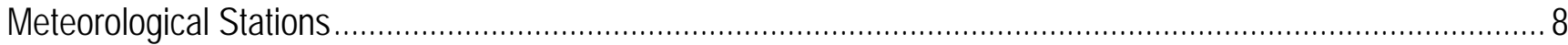

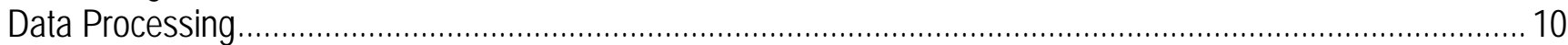

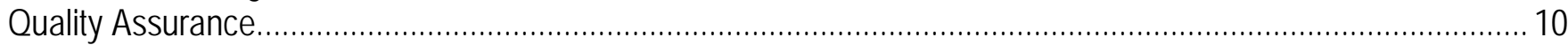

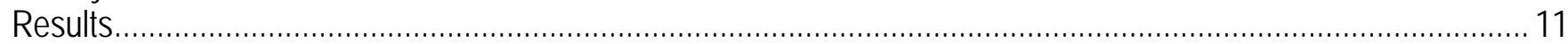

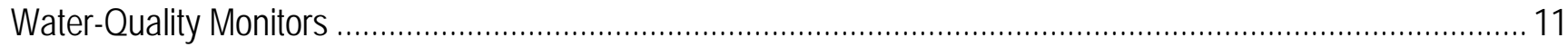

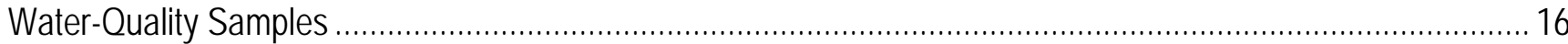

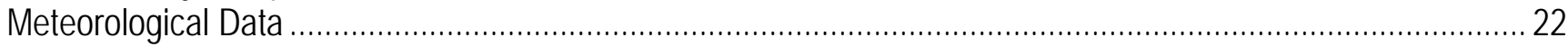

Acknowledgments

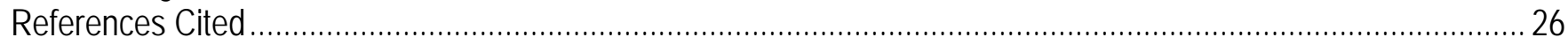

Appendix A. Quality-Control and Quality-Assurance Data for Water-Quality Samples ..........................................2

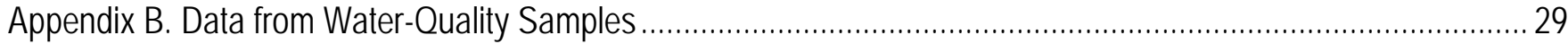

\section{Figures}

Figure 1. Map showing location of meteorological, continuous water-quality monitoring, and water-quality sampling stations, Upper Klamath and Agency Lakes, Oregon, 2007-08

Figure 2. Graphs showing lakewide daily median dissolved oxygen concentration, dissolved oxygen percent saturation, pH, specific conductance, and temperature in Upper Klamath Lake, Oregon, 2005-08.

Figure 3. Graphs showing dissolved oxygen concentration, dissolved oxygen percent saturation, pH, specific conductance, and temperature in Agency Lake, Oregon, 2007.

Figure 4. Graphs showing dissolved oxygen concentration, dissolved oxygen percent saturation, pH, specific conductance, and temperature in Agency Lake, Oregon, 2008.

Figure 5. Graphs showing total nitrogen, total phosphorus, orthophosphate, ammonia, and nitrite-plus-nitrate concentrations, Upper Klamath Lake, Oregon, 2007.

Figure 6. Graphs showing total nitrogen, total phosphorus, orthophosphate, ammonia, and nitrite-plus-nitrate concentrations, Upper Klamath Lake, Oregon, 2008..

Figure 7. Graph showing chlorophyll a concentrations, Upper Klamath Lake, Oregon, 2008 .............................. 20

Figure 8. Graph showing unionized ammonia concentrations, Upper Klamath Lake, Oregon, 2007. .................... 21

Figure 9. Graph showing unionized ammonia concentrations, Upper Klamath Lake, Oregon, 2008 .................... 21

Figure 10. Graph showing dissolved organic carbon concentrations, Upper Klamath Lake, Oregon, 2007 ............ 22

Figure 11. Graph showing lakewide daily median air temperature (number of stations, relative humidity, daytime solar radiation, and wind speed, Upper Klamath Lake, Oregon, 2007-08..................................................... 23

Figure 12. Histograms showing wind speed and direction for meteorological stations near Upper Klamath Lake, Oregon, 2007.

Figure 13. Histograms showing wind speed and direction for meteorological stations near Upper Klamath Lake, Oregon, 2008. 


\section{Tables}

Table 1. Continuous water quality monitoring and sampling stations, Upper Klamath and Agency Lakes, Oregon, 2007-08.

Table 2. Meteorological stations and parameters measured, Upper Klamath Lake, Oregon, 2007-08. 5

Table A1. Quality-control and quality-assurance data for water-quality samples in Upper Klamath Lake, Oregon, 2007.

Table A2. Quality-control and quality-assurance data for water-quality samples in Upper Klamath Lake, Oregon, 2008.

Table B1. Data from water-quality samples, Upper Klamath Lake, Oregon, 2007.

Table B2. Data from water-quality samples, Upper Klamath Lake, Oregon, 2008. 


\section{Conversion Factors, Datums, and Abbreviations and Acronyms}

\section{Conversion Factors}

\begin{tabular}{lll}
\hline \multicolumn{1}{c}{ Multiply } & \multicolumn{1}{c}{ By } & \multicolumn{1}{c}{ To obtain } \\
\hline liter $(\mathrm{L})$ & 1.057 & quart $(\mathrm{qt})$ \\
meter $(\mathrm{m})$ & 3.281 & foot $(\mathrm{ft})$ \\
meter per second $(\mathrm{m} / \mathrm{s})$ & 3.281 & foot per second $(\mathrm{ft} / \mathrm{s})$ \\
microgram per liter $(\mu \mathrm{g} / \mathrm{L})$ & 1.0 & part per billion $(\mathrm{ppb})$ \\
micrometer $(\mu \mathrm{m})$ & $3.937 \times 10^{-5}$ & inch (in) \\
milligram per liter $(\mathrm{mg} / \mathrm{L})$ & 1.0 & part per million $(\mathrm{ppm})$ \\
milliliter $(\mathrm{mL})$ & 0.03382 & fluid ounce $(\mathrm{oz})$ \\
square kilometer $\left(\mathrm{km}^{2}\right)$ & 0.3861 & square mile $\left(\mathrm{mi}{ }^{2}\right)$ \\
watts per square meter $\left(\mathrm{W} / \mathrm{m}^{2}\right)$ & 0.3170 & BTU per square foot $\left(\mathrm{BTU} / \mathrm{ft}^{2}\right)$ \\
\hline
\end{tabular}

Temperature in degrees Celsius $\left({ }^{\circ} \mathrm{C}\right)$ can be converted to degrees Fahrenheit $\left({ }^{\circ} \mathrm{F}\right)$ as follows:

${ }^{\circ} \mathrm{F}=\left(1.8 \mathrm{x}^{\circ} \mathrm{C}\right)+32$.

\section{Datums}

Vertical coordinate information is referenced to the Bureau of Reclamation datum, which is 1.78 feet above National Geodetic Vertical Datum of 1929 (NGVD 29).

Horizontal coordinate information is referenced to the North American Datum of 1927 (NAD 27).

Abbreviations and Acronyms

\begin{tabular}{ll}
\hline \multicolumn{1}{c}{$\begin{array}{c}\text { Abbreviations and } \\
\text { Acronyms }\end{array}$} & \multicolumn{1}{c}{ Definition } \\
\hline ADAPS & Automated Data Processing System \\
ADCP & acoustic Doppler current profiler \\
AFA & Aphanizomenon flos-aquae \\
$\mathrm{H}_{2} \mathrm{SO}_{4}$ & sulphuric acid \\
$\mathrm{NWIS}_{\mathrm{NWQL}}$ & National Water Information System \\
$\mathrm{SRWQL}$ & National Water Quality Laboratory \\
BRWQL & Sprague River Water Quality Laboratory \\
USGS & Bureau of Reclamation Water Quality Laboratory \\
\hline
\end{tabular}


This page is intentionally blank. 


\title{
Water-Quality Data from Upper Klamath and Agency Lakes, Oregon, 2007-08
}

\author{
By Kristofor E. Kannarr, Dwight Q. Tanner, Mary K. Lindenberg, and Tamara M. Wood
}

\section{Significant Findings}

The U.S. Geological Survey Upper Klamath Lake water-quality monitoring program collected data from multiparameter continuous water-quality monitors, weekly water-quality samples, and meteorological stations during May-November 2007 and 2008. The results of these measurements and sample analyses are presented in this report for 29 stations on Upper Klamath Lake and 2 stations on Agency Lake, as well as quality-assurance data for the water-quality samples. Some of the significant findings from 2007 and 2008 are listed below.

- In 2007-08, ammonia concentrations were at or near the detection limit at all stations during the second week in June, after which they began to increase, with peak concentrations occurring from July through November.

- The concentration of un-ionized ammonia, which can be toxic to aquatic life, first began to increase in mid-June and peaked in July or August at most sites. Concentrations of un-ionized ammonia measured in the Upper Klamath Lake in 2007-08 did not reach concentrations that would have been potentially lethal to suckers.

- Samples collected for the analysis of dissolved organic carbon (DOC) late in the 2007 season showed no evidence of an increase in DOC subsequent to the breaching of the Williamson River Delta levees on October 30.

- In 2007-08, the lakewide daily median of dissolved oxygen concentration began to increase in early June, and peaked in mid- to late June.

- The lakewide daily median pH began to increase from early June and peaked in late June (2007) or early July (2008). Lakewide daily median pH slowly decreased during the rest of both seasons.

- The 2007 lakewide daily median specific conductance values first peaked on July 1, coincident with a peak in dissolved oxygen concentration and $\mathrm{pH}$, followed by a decrease through mid-July. Specific conductance then remained relatively stable until mid-October when a sharp increase began that continued until the end of the season. Lakewide specific conductance values for 2008 steadily increased through the season to a maximum in late September.

- Lakewide daily median temperatures in both years began to increase during the beginning of June and peaked in July. These temperatures persisted until late August to early September when a gradual decrease occurred.

- In 2007-08, water-quality conditions monitored at the Agency Lake northern and southern stations were similar to those in Klamath Lake. 
- Results from water-quality sampling showed that total nitrogen and total phosphorus concentrations generally began to increase in mid-June in the 2007-08 seasons, with peak concentrations occurring from July through October.

- During the 2007-08 field seasons, the lakewide daily median air temperature increased through the beginning of June until mid-July before decreasing in September; relative humidity had an opposite trend.

- Wind speed varied during the first and last parts of the season and was relatively calm between July and September. The highest winds were predominantly from the northwest and the west.

\section{Introduction}

\section{Background}

Severe water-quality problems in Upper Klamath Lake (fig. 1) have led to critical fishery concerns, including the listing of Lost River and shortnose suckers as endangered in 1988 (Stubbs and White, 1993). The lake's algal community has shifted to a near monoculture of Aphanizomenon flosaquae (AFA) during summer (Kann, 1997; Perkins and others, 2000), and massive blooms of the alga have directly coincided with episodes of poor water quality in Upper Klamath Lake characterized by high $\mathrm{pH}$ (as much as 9-10), widely variable dissolved oxygen (anoxic to supersaturated), and high unionized ammonia concentrations (>0.5 mg/L) (Hoilman and others, 2008; Lindenberg and others, 2008). Large AFA blooms and the accompanying degraded water-quality conditions are also present annually in Agency Lake.

The U.S. Geological Survey (USGS), in cooperation with the Bureau of Reclamation, began monitoring water quality in Upper Klamath Lake in 2002. Before 2002, there were no continuous datasets of temperature, $\mathrm{pH}$, dissolved oxygen, or specific conductance of well-documented quality and spanning several months during the spring through autumn seasons. The Klamath Tribes have collected biweekly water samples for nutrients and chlorophyll $a$ at 10 stations in Upper Klamath and Agency Lakes since 1990. Studies that have used this dataset, which is the longest consistent record of water quality in Upper Klamath Lake, include Kann (2007) and Morace (2007).

From 2002 through 2004, continuous water-quality monitoring by the USGS was limited to the northern part of Upper Klamath Lake, where the monitoring supported a telemetry tracking study of endangered adult suckers (Wood and others, 2006). The 3 years of monitoring showed that the occurrence and severity of poor water-quality conditions in Upper Klamath Lake were unpredictable from year to year. However, in each year, seasonal patterns of low dissolved oxygen and high $\mathrm{pH}$ were well correlated with the dynamics of annual AFA blooms (Hoilman and others, 2008). Seasonally low dissolved oxygen concentrations, for example, tended to occur near the end of July or beginning of August coincident with a collapse of the AFA bloom. A fish die-off in 2003 was associated with a particularly severe low dissolved oxygen event that coincided with a bloom decline at the end of July (Banish and others, 2009). 


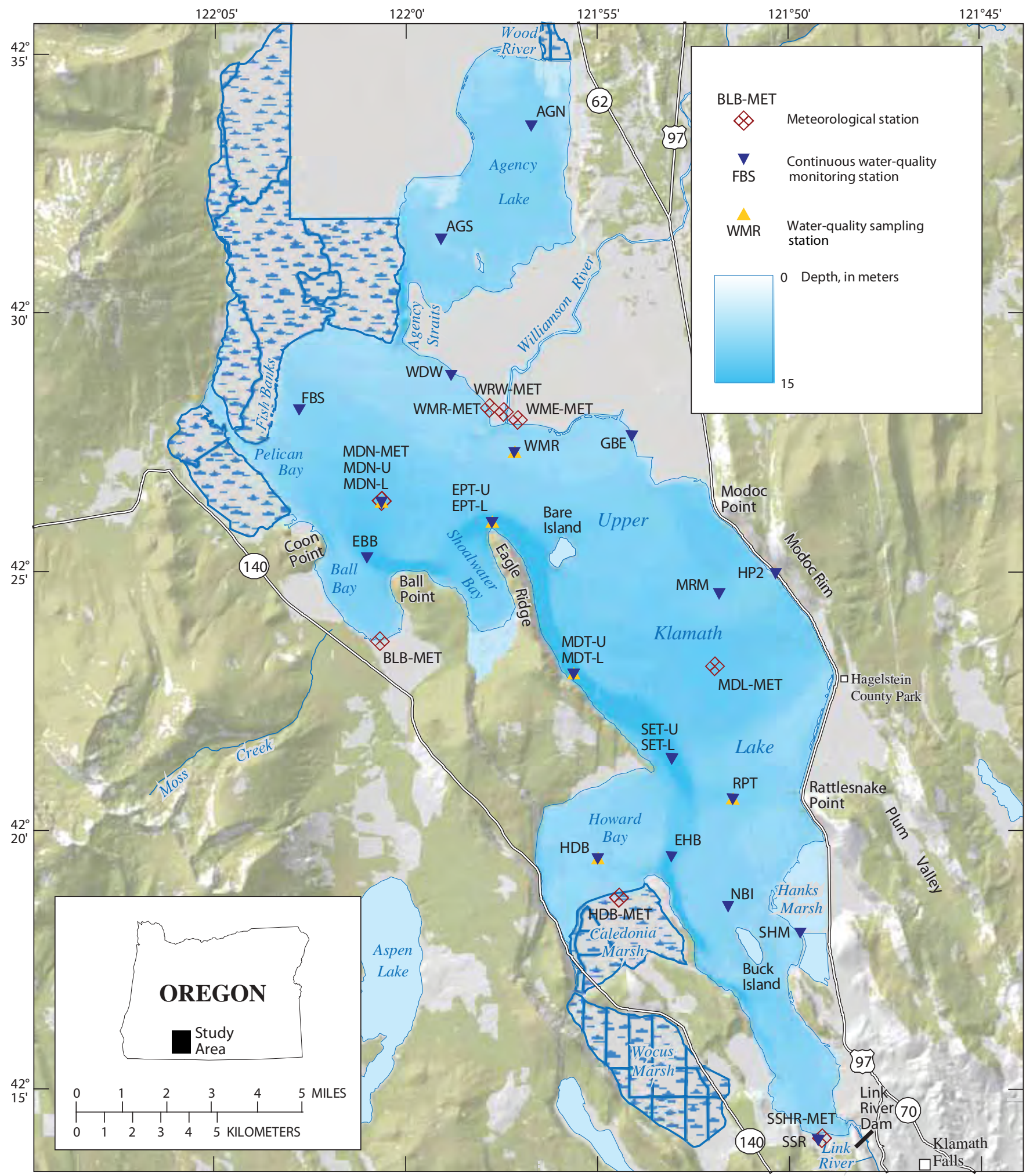

Bathymetry produced by Glen Canyon Environmental Studies in cooperation wtth Bureau of Reclamation, Mid-Pacif ic Reg on K a mat h Bas $\mathrm{n}$ A ea Off i⿺, and the K I amatribes. Digital Raster Graphics and Elevation modif i edfr o mUS Ged og cd Survy, various scales. Base map digital data, USGS, various sources. Projection: UTM, Zone 10, NAD83 horizontal datum. 
Figure 1. Location of meteorological, continuous water-quality monitoring, and water-quality sampling stations, Upper Klamath and Agency Lakes, Oregon, 2007-08. Station descriptions are shown in table 1.

Circulation patterns in Upper Klamath Lake have been explored with measurements and modeling. Current velocity measurements made with acoustic Doppler current profilers (ADCPs; Gartner and others, 2007) and hydrodynamic modeling with the three-dimensional UnTRIM model (Wood and others, 2008) have confirmed that during periods of prevailing northwesterly winds, circulation is clockwise around the lake. The circulation forms a broad, shallow, southward flow through most of the lake and along the northern and eastern shorelines, and a narrow, deep, northward flow through the trench along the western shoreline. The circulation patterns of the wind-driven currents indicate that poor water-quality conditions, particularly low dissolved oxygen, that are sometimes observed in the northern part of the lake do not necessarily originate locally. These conditions can develop farther south in the lake, particularly in the deep trench, and be transported through the trench west of Bare Island into the northern part of the lake by the prevailing currents (Wood and others, 2008).

In 2005, the USGS water-quality monitoring program on Upper Klamath Lake expanded to include most of Upper Klamath Lake as well as monitoring stations in Agency Lake. Additional meteorological stations were established around the lake basin to provide greater resolution of meteorological data used in modeling water movement and heat transport. Agency Lake was found to have a seasonal cycle of AFA bloom and decline similar to, but independent from, that of Upper Klamath Lake. Dissolved oxygen production and consumption experiments in Upper Klamath Lake provided evidence of decreasing photosynthetic dissolved oxygen production through July that was reflected in the continuous-monitor data (Hoilman and others, 2008). The transport of poor waterquality conditions northward through the trench by prevailing currents into the northern part of the lake also was observed.

In 2006, water-quality monitoring showed seasonal patterns similar to those in 2005; these patterns were closely related to the bloom dynamics of AFA. Conditions were documented that were potentially harmful to fish: low dissolved oxygen concentrations and high un-ionized ammonia concentrations in the deepest parts of Upper Klamath Lake, high $\mathrm{pH}$ and possible gas-bubble formation in shallow areas of the lakes. The net production of dissolved oxygen as measured in light bottles incubated in the lake was generally positively correlated with chlorophyll $a$ concentration, and measurements of community respiration from dark bottles indicated that much of the oxygen consumption associated with a rapid decline in the bloom occurred at the sediment-water interface (Lindenberg and others, 2008).

The long-term monitoring effort that began in 2005 continued in 2007-08. This report presents the results of the 2007-08 data-collection program, along with some comparisons to data from 2005 and 2006. Data from continuous water-quality monitors, laboratory analyses of water-quality samples, and data from meteorological sites are included in this report. Previous water-quality data and interpretations are summarized in the following reports: for 2002-04, Wood and others (2006); for 2005, Hoilman and others (2008); and for 2006, Lindenberg and others (2008).

A significant change to the shoreline of Upper Klamath and Agency Lakes occurred during the period covered by this report, related to the flooding of previously drained wetlands on property owned by The Nature Conservancy around the Williamson River Delta. In October 2007, nearly 2 mi of levees separating Upper Klamath and Agency Lakes from the Williamson River Delta were breached, allowing lake water to enter the delta and flood land that had been in agricultural production since the 1940s to 1950s (Erdman and Hendrixson, 2009). Because of the large spatial scale of this disturbance to the system, the monitoring season was extended for approximately 4 weeks to mid-November 2007. 


\section{Description of Study Area}

Upper Klamath Lake (fig. 1) is in south-central Oregon. The lake is large and shallow with a surface area of $232 \mathrm{~km}^{2}$ and an average depth of $2.8 \mathrm{~m}$. Most of the lake (about 90 percent) is shallower than $4 \mathrm{~m}$, except for a narrow trench running parallel to Eagle Ridge, on the lake's western shore. This trench is as much as $15 \mathrm{~m}$ deep. Upper Klamath Lake is in the Klamath Graben structural valley; much of its $9,415-\mathrm{km}^{2}$ drainage basin is composed of volcanically derived soils. The largest single source of inflow to the lake is the Williamson River, which contributes nearly one-half, on average, of incoming water (Hubbard, 1970) and enters the lake near its northern end.

Upper Klamath Lake is a natural water body, but lake-surface elevations have been regulated since 1921, when Link River Dam was completed at the southern outlet of the lake. The dam was built, and currently is operated, by the Bureau of Reclamation. The lake is now the primary water source for the Klamath Project, an irrigation system developed to supply water to farms and ranches in and around the Upper Klamath Basin (Bureau of Reclamation, 2000). Agency Lake, just north of Upper Klamath Lake, is connected to Upper Klamath Lake by a narrow natural channel and adds about $38 \mathrm{~km}^{2}$ of surface area to the Upper Klamath Lake-Agency Lake hydrologic system (Johnson, 1985). Agency Lake is also shallow, with a maximum depth of about $3 \mathrm{~m}$ and an average depth of $0.9 \mathrm{~m}$. Like Upper Klamath Lake, Agency Lake is hypereutrophic, with annual blooms of AFA. Because the channel connecting Upper Klamath Lake and Agency Lake is narrow compared to the two water bodies and the discharge through it is small, the two lakes are largely independent in terms of the seasonal AFA bloom and water-quality dynamics.

\section{Methods}

\section{Continuous Water-Quality Monitors}

YSI model 600XLM continuous water-quality monitors ("sondes”) were placed at 2 stations in Agency Lake and 23 stations in Upper Klamath Lake (fig. 1, table 1). In Upper Klamath Lake, 18 monitors were in open-water areas and 5 monitors were in nearshore areas (5-10 m from shore or in reed beds adjacent to the open lake). Nearshore stations were HP2, SHM, SSR, GBE, and WDW.

Table 1. Continuous water quality monitoring and sampling stations, Upper Klamath and Agency Lakes, Oregon, 2007-0ह

[Locations of stations are shown in figure 1. Stations are shown in order of decreasing depth.]

\begin{tabular}{llcccc}
\hline \multicolumn{1}{c}{ Station name } & $\begin{array}{c}\text { Station name } \\
\text { abbreviation }\end{array}$ & $\begin{array}{c}\text { USGS station } \\
\text { identification no. }\end{array}$ & $\begin{array}{c}\text { Latitude } \\
\text { (north) }\end{array}$ & $\begin{array}{c}\text { Longitude } \\
\text { (west) }\end{array}$ & $\begin{array}{c}\text { Full-pool } \\
\text { measured } \\
\text { depth } \\
\text { (meters) }\end{array}$ \\
\hline Middle of trench (lower) & MDT-L & Openwater stations & & & \\
Middle of trench (upper) & MDT-U & 422305121553800 & $42^{\circ} 23^{\prime} 05^{\prime \prime}$ & $121^{\circ} 55^{\prime} 38^{\prime \prime}$ & 15.0 \\
Eagle Point (lower) & EPT-L & 422559121574400 & $42^{\circ} 25^{\prime} 59^{\prime \prime}$ & $121^{\circ} 57^{\prime} 44^{\prime \prime}$ & 12.5 \\
Eagle Point (upper) & EPT-U & 422559121574403 & $42^{\circ} 25^{\prime} 59^{\prime \prime}$ & $121^{\circ} 57^{\prime} 44^{\prime \prime}$ & 12.5 \\
Entrance to Ball Bay & EBB & 422519122005800 & $42^{\circ} 25^{\prime} 19^{\prime \prime}$ & $122^{\circ} 00^{\prime} 58^{\prime \prime}$ & 7.5
\end{tabular}


Table 1. Continuous water quality monitoring and sampling stations, Upper Klamath and Agency Lakes, Oregon, 2007-08—continued.

[Locations of stations are shown in figure 1. Stations are shown in order of decreasing depth.]

\begin{tabular}{|c|c|c|c|c|c|}
\hline Station name & $\begin{array}{l}\text { Station name } \\
\text { abbreviation }\end{array}$ & $\begin{array}{l}\text { USGS station } \\
\text { identification no. }\end{array}$ & $\begin{array}{l}\text { Latitude } \\
\text { (north) }\end{array}$ & $\begin{array}{l}\text { Longitude } \\
\text { (west) }\end{array}$ & $\begin{array}{c}\text { Full-pool } \\
\text { measured } \\
\text { depth } \\
\text { (meters) }\end{array}$ \\
\hline \multicolumn{6}{|c|}{ Openwater stations-continued } \\
\hline South End of Trench (lower) & SET-L & 422128121530600 & $42^{\circ} 21 ' 28^{\prime \prime}$ & $121^{\circ} 53^{\prime} 06^{\prime \prime}$ & 7.0 \\
\hline South End of Trench (upper) & SET-U & 422128121530603 & $42^{\circ} 21 ' 28^{\prime \prime}$ & $121^{\circ} 53^{\prime} 06^{\prime \prime}$ & 7.0 \\
\hline Entrance to Howard Bay & EHB & 421935121530600 & $42^{\circ} 19 ' 35^{\prime \prime}$ & $121^{\circ} 53^{\prime} 06^{\prime \prime}$ & 5.2 \\
\hline Midnorth (lower) & MDN-L & 422622122004000 & $42^{\circ} 26^{\prime} 22^{\prime \prime}$ & $122^{\circ} 00^{\prime} 40^{\prime \prime}$ & 4.2 \\
\hline Midnorth (upper) & MDN-U & 422622122004003 & $42^{\circ} 26^{\prime} 22^{\prime \prime}$ & $122^{\circ} 00^{\prime} 40^{\prime \prime}$ & 4.2 \\
\hline Modoc Rim & MRM & 422437121515200 & $42^{\circ} 24 ' 37^{\prime \prime}$ & $121^{\circ} 51^{\prime} 52^{\prime \prime}$ & 3.7 \\
\hline Rattlesnake Point & RPT & 422042121513100 & $42^{\circ} 20^{\prime} 42^{\prime \prime}$ & 12151'31" & 3.4 \\
\hline Agency North & AGN & 423335121564300 & $42^{\circ} 33^{\prime} 35^{\prime \prime}$ & $121^{\circ} 56^{\prime} 43^{\prime \prime}$ & 3.0 \\
\hline Fish Banks & FBS & 422808122024400 & $42^{\circ} 28^{\prime} 08^{\prime \prime}$ & $122^{\circ} 02^{\prime} 44^{\prime \prime}$ & 2.8 \\
\hline North Buck Island & NBI & 421838121513900 & $42^{\circ} 18 ' 38^{\prime \prime}$ & $121^{\circ} 51^{\prime} 39 "$ & 2.8 \\
\hline $\begin{array}{l}\text { Upper Klamath Lake at } \\
\text { Williamson River outlet }\end{array}$ & WMR & 422719121571400 & $42^{\circ} 27^{\prime} 19^{\prime \prime}$ & $121^{\circ} 57^{\prime} 14^{\prime \prime}$ & 2.5 \\
\hline Agency South & AGS & 423124121583400 & $42^{\circ} 31^{\prime} 25^{\prime \prime}$ & $121^{\circ} 59^{\prime} 03^{\prime \prime}$ & 2.5 \\
\hline Howard Bay & HDB & 421933121550000 & $42^{\circ} 19^{\prime} 33^{\prime \prime}$ & $121^{\circ} 55^{\prime} 00^{\prime \prime}$ & 2.2 \\
\hline \multicolumn{6}{|c|}{ Nearshore stations } \\
\hline Hagelstein Park II & HP2 & 422500121502800 & $42^{\circ} 25^{\prime} 00^{\prime \prime}$ & $121^{\circ} 50^{\prime} 28^{\prime \prime}$ & 3.4 \\
\hline South Hanks March & SHM & 421805121494800 & $42^{\circ} 18^{\prime} 05^{\prime \prime}$ & $121^{\circ} 49^{\prime} 48^{\prime \prime}$ & 2.2 \\
\hline South Shore & SSR & 421410121492000 & $42^{\circ} 14^{\prime} 10^{\prime \prime}$ & $121^{\circ} 49^{\prime} 20^{\prime \prime}$ & 2.5 \\
\hline Goose Bay East & GBE & 422749121540700 & $42^{\circ} 27^{\prime} 39^{\prime \prime}$ & $121^{\circ} 54^{\prime} 08^{\prime \prime}$ & 2.4 \\
\hline Williamson Delta West & WDW & 422842121584300 & $42^{\circ} 28^{\prime} 42^{\prime \prime}$ & $121^{\circ} 58^{\prime} 43^{\prime \prime}$ & 2.2 \\
\hline
\end{tabular}


At most continuous water-quality monitoring stations, sondes were placed horizontally at a fixed depth of $1 \mathrm{~m}$ from the lake bottom; if the depth at a station was less than $2 \mathrm{~m}$, the sonde was placed at the midpoint of the water column. The $1 \mathrm{~m}$ from the lake bottom depth for sonde placement was selected to provide data relevant to the endangered suckers of Upper Klamath Lake, which are bottomfeeding fish. A second sonde was placed on the same mooring at a fixed depth $1 \mathrm{~m}$ from the surface at the four deepest stations, SET, MDT, EPT, and MDN, to monitor water-quality conditions near the water surface and provide comparisons to conditions near the lake bottom, All sondes recorded depth, dissolved oxygen concentration, $\mathrm{pH}$, specific conductance, and temperature at the beginning of every hour.

Sondes were cleaned and field measurements of station depth were made during weekly station visits to ensure proper placement of the instrument in the water column. Separate field measurements of dissolved oxygen concentration, $\mathrm{pH}$, specific conductance, and temperature at the depth of the station sonde were made as an additional check of sonde performance. Deployments generally lasted 3 weeks, and then the sonde at the station was replaced with a newly calibrated instrument. Calibration of each parameter was checked in the laboratory after sonde retrieval to measure calibration drift. The raw data were then uploaded to the USGS automated data-processing system (ADAPS). Quality of the data was assured by the field information collected during weekly station visits and by processing the time series according to the procedures in Wagner and others (2006). Corrections to data due to biological fouling and drift as determined during the post-deployment calibration check were entered into ADAPS, which calculated the corrected values.

\section{Collection of Water-Quality Samples}

Water samples were collected in the summers of 2007-08 on a weekly basis according to established protocols (U.S. Geological Survey, variously dated). Samples were collected for 25 weeks between mid-May and mid-November in 2007, and 21 weeks between mid-May and mid-October in 2008. The longer season in 2007 allowed conditions to be monitored for about 6 weeks after the breaching of the levees at the Williamson River Delta. Samples were analyzed for total phosphorus, total nitrogen, chlorophyll $a$, pheophytin $a$, total ammonia (ammonia plus ammonium), orthophosphate, and nitrite-plus-nitrate concentrations. Additionally, samples from late 2007 were analyzed for dissolved organic carbon. Chlorophyll $a$ from 2007 and pheophytin $a$ data were deemed to be of insufficient quality and are not reported. Water samples were collected at the continuous water-quality monitoring stations MDT, EPT, MDN, RPT (2007 only), WMR, and HDB (2007 only) (fig. 1). Two stations-MRM and NBI-were added to the sample-collection effort in 2007 starting in the second week of October to better monitor conditions in the lake subsequent to the breaching of levees at the Williamson River Delta.

Two methods of sampling were used, depending on the analyte to be measured. Water samples analyzed for total phosphorus, total nitrogen, chlorophyll $a$, and pheophytin $a$ were collected in such a way as to achieve an equal integration over the depth of the water column. Depth-integrated samples were collected in two 2-L bottles held in a weighted cage that was lowered at a constant rate into the water to $0.5 \mathrm{~m}$ from the bottom at stations less than 10.5-m depth ("shallow" stations) and to $10 \mathrm{~m}$ from the surface at stations greater than 10.5-m depth (“deep” stations). Two small ports were included in each bottle, one for water to flow in, and one for the escape of displaced air. The contents of bottles from multiple collections at a station were composited, mixed, and then split into separate replicate fractions using a churn splitter. 
Water samples analyzed for dissolved nutrients (ammonia, orthophosphate, and nitrite plus nitrate) were collected from a point mid-depth in the water column at the shallow stations MDN, MRM, WMR, HDB, NBI, and RPT. At the deeper stations (MDT and EPT), water was collected at two points in the water column (at one-quarter and three-quarters of the total depth). Point samples were collected by lowering one end of a hose to the appropriate depth in the water column, then passing the sample through a $0.45-\mu m$ capsule filter using a peristaltic pump.

Dissolved nutrient, total phosphorus, and total nitrogen samples were chilled onsite and sent to the laboratory for analysis. Total phosphorus and total nitrogen samples were preserved in the field with $1 \mathrm{~mL}$ of 4.5 normal (4.5N) $\mathrm{H}_{2} \mathrm{SO}_{4}$. In 2008, samples for chlorophyll $a$ and pheophytin $a$ analyses were passed through a $0.45-\mu \mathrm{m}$ glass-fiber filter, and the filter membrane was frozen and sent to the Bureau of Reclamation Water Quality Laboratory (BRWQL) in Boise, Idaho. In 2007, nutrient samples were sent to the National Water Quality Laboratory (NWQL) in Denver, Colorado. In 2008, nutrient samples were sent to the Sprague River Water Quality Laboratory (SRWQL) in Chiloquin, Oregon, a laboratory that participates in the USGS Standard Reference Sample Project. Finalized data from all laboratories were stored in the USGS National Water Information System (NWIS) database.

\section{Meteorological Stations}

The locations of meteorological measurement stations in Upper Klamath Lake are shown in figure 1 and listed in table 2. During the study period, the station near the mouth of the Williamson River was moved twice to accommodate construction associated with the restoration of the Williamson River Delta. In May 2007, the station was moved from WMR to WME, where the instrumentation stayed until April 2008, when it was moved to WRW. Wind-speed and direction data were collected by an R.M. Young ${ }^{\mathrm{TM}}$ model 05103 wind monitor. Air temperature and relative humidity data were collected by a Campbell Scientific ${ }^{\circledR}$ CS215 or HMP35C relative humidity and air-temperature sensor. Additionally, solar-radiation data were collected at the WMR, WME, and WRW-MET stations using a Li-Cor LI200SZ pyranometer and at the SSHR MET station using Eppley Laboratory model PSP and PIR pyranometers. Floating stations were similar to the land-based stations, although the mast attached to the buoy provided a height, measured from the surface of the water, of $2 \mathrm{~m}$ for wind monitors and 1.5 $\mathrm{m}$ for relative humidity and temperature sensors. Data collected from all sensors at a station were stored every 10 minutes by a Campbell Scientific CR510, CR10, or CR10X data logger at the station. A 12volt battery at the station charged by a solar-power array provided power. Data were collected during station visits approximately every 2 weeks during the field season. During these visits, sensors were checked for proper function by comparison with hand-held instruments and were cleaned and maintained as needed. Information necessary to correct data due to drifts from proper calibration was collected as needed. Raw meteorological data were loaded into ADAPS and processed in the same manner as the water-quality monitor data.

Wind speed and direction determine the circulation patterns of the water in Upper Klamath Lake. This phenomenon has been verified with a hydrodynamic model of the lake (Wood and others, 2008) and with the placement of ADCPs in the lake (Wood and others, 2006). Because the wind and the currents are so tightly coupled, the preliminary modeling effort also determined that spatially accurate wind data from the entire lake are required, rather than data collected from only a single station. For this reason, starting in 2005, wind and other meteorological data were collected year-round at four stations located on the shoreline of Upper Klamath Lake. In 2007-08, meteorological data were collected at the same stations in continued support of the modeling effort (fig. 1, table 2). 
Table 2. Meteorological stations and parameters measured, Upper Klamath Lake, Oregon, 2007-08.

[Site locations are shown in figure 1. USGS station identification no. is a unique number for each station based on the latitude and longitude of the station. First six digits are latitude, next eight digits are longitude, and final two digits are a sequence number to uniquely identify each station. USGS, U.S. Geological Survey]

\begin{tabular}{|c|c|c|c|c|c|}
\hline $\begin{array}{c}\text { Meteorological } \\
\text { station name }\end{array}$ & $\begin{array}{l}\text { Station name } \\
\text { abbreviation }\end{array}$ & $\begin{array}{l}\text { USGS station } \\
\text { identification no. }\end{array}$ & Latitude (north) & Longitude (west) & $\begin{array}{c}\text { Parameters } \\
\text { measured }\end{array}$ \\
\hline Midnorth $^{1}$ & MDN-MET & 422622122004000 & $42^{\circ} 26^{\prime} 21^{\prime \prime}$ & $122^{\circ} 00^{\prime} 40^{\prime \prime}$ & $\begin{array}{l}\text { Wind speed and } \\
\text { direction }\end{array}$ \\
\hline $\begin{array}{l}\text { Williamson River } \\
(6 / 05-5 / 07)\end{array}$ & WMR-MET & 422809121574800 & $42^{\circ} 28^{\prime} 09^{\prime \prime}$ & $121^{\circ} 57^{\prime} 48^{\prime \prime}$ & $\begin{array}{l}\text { Wind speed and } \\
\text { direction, air } \\
\text { temperature, relative } \\
\text { humidity, solar } \\
\text { radiation }\end{array}$ \\
\hline $\begin{array}{l}\text { Williamson Mouth } \\
\text { East (5/07-4/08) }\end{array}$ & WME-MET & 422801121572000 & $42^{\circ} 28^{\prime} 01^{\prime \prime}$ & $121^{\circ} 57^{\prime} 20^{\prime \prime}$ & $\begin{array}{l}\text { Wind speed and } \\
\text { direction, air } \\
\text { temperature, relative } \\
\text { humidity, solar } \\
\text { radiation }\end{array}$ \\
\hline $\begin{array}{l}\text { Williamson River } \\
\text { West (4/08-10/09) }\end{array}$ & WRW-MET & 422807121572500 & $42^{\circ} 28^{\prime} 07^{\prime \prime}$ & $121^{\circ} 57^{\prime} 25^{\prime \prime}$ & $\begin{array}{l}\text { Wind speed and } \\
\text { direction, air } \\
\text { temperature, relative } \\
\text { humidity, solar } \\
\text { radiation }\end{array}$ \\
\hline Ball Bay & BLB-MET & 422341122003800 & $42^{\circ} 23^{\prime} 41^{\prime \prime}$ & $122^{\circ} 00^{\prime} 38^{\prime \prime}$ & $\begin{array}{l}\text { Wind speed and } \\
\text { direction, air } \\
\text { temperature, relative } \\
\text { humidity }\end{array}$ \\
\hline Midlake $^{1}$ & MDL-MET & 422312121515900 & $42^{\circ} 23^{\prime} 12^{\prime \prime}$ & $121^{\circ} 51^{\prime} 59^{\prime \prime}$ & $\begin{array}{l}\text { Wind speed and } \\
\text { direction, air } \\
\text { temperature, relative } \\
\text { humidity }\end{array}$ \\
\hline Howard Bay & HDB-MET & 421846121542800 & $42^{\circ} 18^{\prime} 46^{\prime \prime}$ & $121^{\circ} 54^{\prime} 28^{\prime \prime}$ & $\begin{array}{l}\text { Wind speed and } \\
\text { direction, air } \\
\text { temperature, relative } \\
\text { humidity }\end{array}$ \\
\hline South Shore & SSHR-MET & 421402121491400 & $42^{\circ} 14^{\prime} 03^{\prime \prime}$ & $121^{\circ} 49^{\prime} 14^{\prime \prime}$ & $\begin{array}{l}\text { Wind speed and } \\
\text { direction, air } \\
\text { temperature, relative } \\
\text { humidity, solar } \\
\text { radiation }\end{array}$ \\
\hline
\end{tabular}

Floating site 


\section{Data Processing}

Before calculating statistics, data from continuous water-quality monitors were screened using temporal and, when appropriate for the statistic, spatial criteria. For this report, daily statistics were used for continuous water-quality monitor data. To ensure that data were acceptable to compute daily statistics, at least 80 percent of measurements from one station for 1 day had to be present, which would constitute a "qualifying day" of data. A spatial criterion was applied when data collected from the entire lake were compiled to compute a statistic, such as lakewide daily median dissolved oxygen. This criterion specified that at least 70 percent of water-quality stations in the lake had to have qualifying daily data to compute the lakewide statistic for a particular day.

For statistics at individual meteorological stations, the temporal criterion required that at least 80 percent of possible measurements made in 1 day were present to constitute a qualifying day of data. Different levels of spatial acceptability were applied to compute lakewide meteorological statistics depending on the parameter because not all parameters were collected at all stations, and relatively few meteorological stations were installed around the Upper Klamath Lake basin. Air-temperature and relative-humidity data were collected at five stations, so the spatial criterion for these parameters required that daily qualifying data were available at four of the five stations (80 percent) to compute a lakewide daily statistic. Wind-speed data were collected at all meteorological stations, so the spatial criterion for wind speed required that daily qualifying data were available at five of the six stations (83 percent) to compute a lakewide daily statistic. Because solar-radiation data were collected at only two stations, these data were not screened according to spatial criteria.

\section{Quality Assurance}

Quality-assurance samples were collected for dissolved nutrients, total phosphorus, total nitrogen, chlorophyll $a$, phaeophytin $a$, and dissolved organic carbon. These samples included field blanks (usually the first sample collected every week) and either a replicate or a split sample (duplicate), (each type every other week). Field blanks were samples of deionized water obtained from NWQL and processed onsite through clean sampling equipment before an environmental sample was collected. Analysis of blank samples determines if the processes of collection, handling, transport, and analysis cause measurable contamination. Replicate samples are environmental samples collected twice in rapid succession from the same location and analyzed to determine variability of the system and variability in the analytical methods.

Split samples are environmental water samples collected once and divided into two or more samples that are used to determine the variability in the analytical methods. In 2007, samples were analyzed by NWQL, and routine split samples also were sent to NWQL (table A1). In addition, split nutrient samples were submitted blindly to BRWQL and Aquatic Research, Inc. of Seattle, Washington (table A1). In 2008, samples were analyzed by SRWQL, and routine split samples also were sent to that laboratory (table A2). Blind interlaboratory splits were submitted to NWQL, BRWQL, and Aquatic Research, Inc. (table A2). Additionally, in 2008, spiked samples were prepared the USGS Klamath Falls Field Station and reference samples were prepared at the USGS Oregon Water Science Center. Reference samples for nutrients were prepared by spiking blank water; reference samples for chlorophyll a were prepared by spiking a solution of $90 \%$ acetone and $10 \%$ deionized water. Nutrient and chlorophyll a concentrated spike solutions were prepared by the NWQL. Spiked and reference samples were submitted blindly to the SRWQL and the BRWQL for analysis (table A2). 
NWQL has quality-assurance protocols that include standard reference samples, blanks, replicates, spikes, and calibration standards. These protocols are documented in Friedman and Erdmann (1982), Jones (1987), Pritt and Raese (1995), and Maloney (2005). Samples analyzed at NWQL were collected using USGS-certified field supplies, including filters, bottles, and preservatives. Those supplies are subject to testing, inspection, and other quality-assurance procedures (U.S. Geological Survey, 2007).

Quality-assurance findings are summarized in appendix A, tables A1 and A2. In 2007, the largest percentage of blank samples with concentrations larger than the minimum reporting level (MRL) was 45 percent for dissolved organic carbon (table A1). Concentrations of the environmental waterquality samples were all larger than the MRL of $0.4 \mathrm{mg} / \mathrm{L}$, ranging from 3.6 to $8.6 \mathrm{mg} / \mathrm{L}$. The mean value of the blanks was equivalent to only 16.7 percent of the mean value of the environmental concentrations, indicating that the dissolved organic carbon data was of acceptable quality. The split and replicate samples in 2007 for dissolved organic carbon and nutrients showed mean percent differences ranging from 3.5 to 15.4 percent, indicating that the data were of good quality. The standard deviation of interlaboratory split nutrient samples ranged from 0.008 to 0.31 (table A1).

In 2008, the largest percentage of blank samples with concentrations larger than the MRL was 59 percent for total nitrogen (table A2). Concentrations of the environmental water-quality samples were all larger than the MRL of $0.03 \mathrm{mg} / \mathrm{L}$, ranging from 0.57 to $5.67 \mathrm{mg} / \mathrm{L}$. The mean value of the blanks was equivalent to only 3.0 percent of the mean value of the environmental concentrations, indicating that the total nitrogen data was of acceptable quality. Split and replicate samples in 2008 for nutrients showed mean differences ranging from 2 to 13 percent, indicating that the data were of good quality. The standard deviation of interlaboratory split nutrient samples ranged from 0.00 to 0.21 (table A2). Nutrient spike recoveries for blanks in 2008 ranged from 91.2 to 102.3 percent (table A2). Nutrient spike recoveries for spiked sample matrices were slightly smaller at 78.3 and 89.0 percent (table A2).

\section{Results}

Data from a network of multiparameter continuous water-quality monitors, water-quality samples, and meteorological stations were collected from Upper Klamath and Agency Lakes in 2007-08 to assess water-quality conditions and processes. This network provides information critical to understanding lakewide water-quality dynamics in Upper Klamath and Agency Lakes. The network provides water-quality data at a high temporal resolution that can be related to bloom conditions, weather, bathymetry, and currents, and it is central to future water-quality modeling efforts. Continued operation of the monitoring stations to collect a long-term dataset also will enable the identification of water-quality status and trends in Upper Klamath Lake.

\section{Water-Quality Monitors}

In 2007-08, the lakewide daily median of dissolved oxygen concentration began to increase in early June and peaked in mid- to late June (fig. 2). The 2007 season was characterized by a decrease in dissolved oxygen in early July that was sustained for about 2 weeks before recovering and remaining steady until September. In 2008, several minima and maxima in dissolved oxygen concentration occurred between mid-July and September. Lakewide daily median dissolved oxygen concentration ranged from $5.7 \mathrm{mg} / \mathrm{L}$ on November 9 to $11.2 \mathrm{mg} / \mathrm{L}$ on September 27 in 2007 and $4.8 \mathrm{mg} / \mathrm{L}$ on August 19 to $10.5 \mathrm{mg} / \mathrm{L}$ on November 13 in 2008. Lakewide daily median dissolved oxygen concentration in 2007-08 differed from 2005-06 in that dissolved oxygen concentration in 2005-06 had a single, longer duration decrease near the end of July and a lower minimum. This decrease in both years was associated with the first rapid decline in the AFA bloom (Hoilman and others, 2008; Lindenberg and others, 2008). 

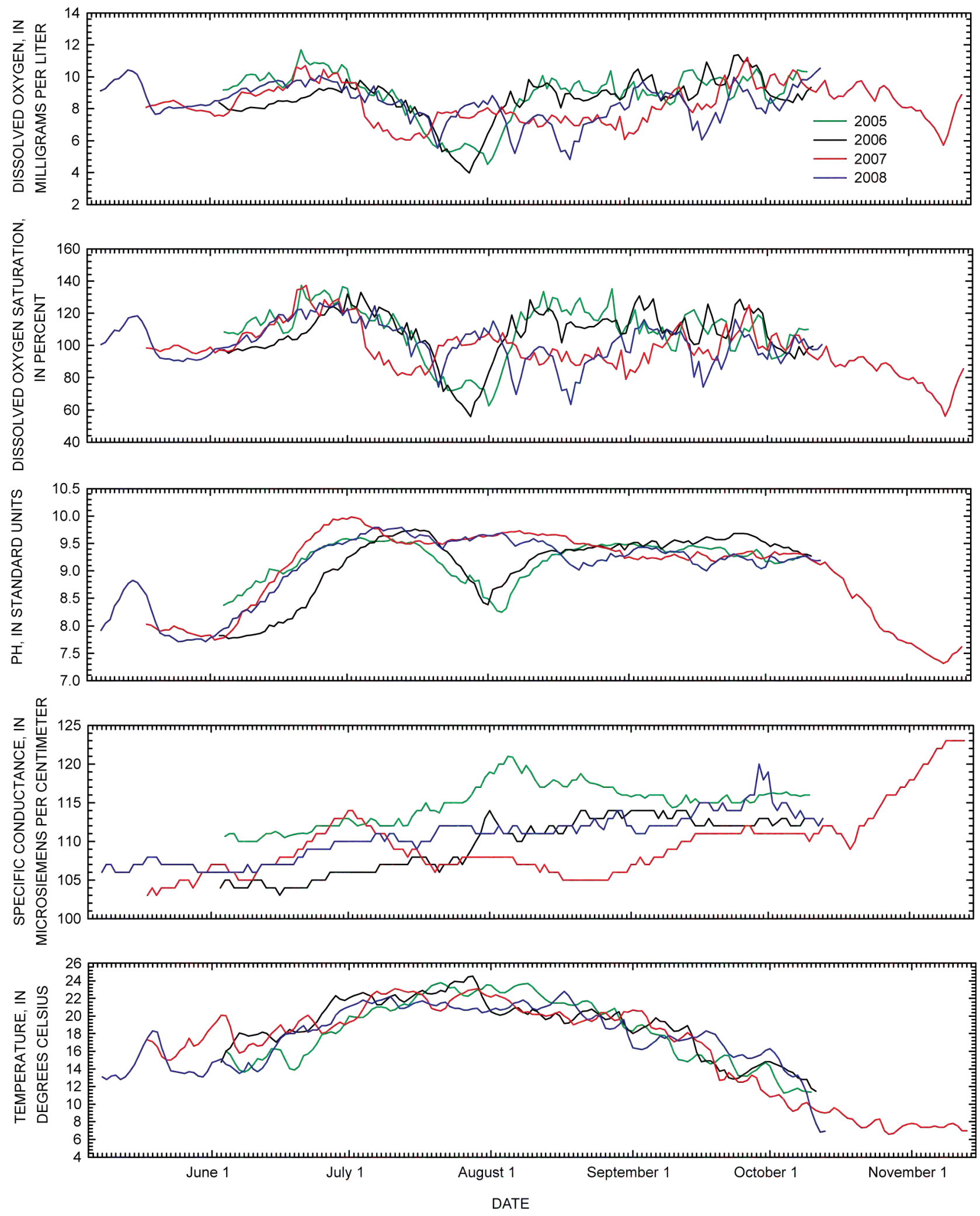

Figure 2. Lakewide daily median dissolved oxygen concentration, dissolved oxygen percent saturation, $\mathrm{pH}$, specific conductance, and temperature in Upper Klamath Lake, Oregon, 2005-08. Sample size is 16. 
In 2007-08, lakewide daily median $\mathrm{pH}$ began to increase from early June and peaked in late June (2007) or early July (2008). Lakewide daily median pH slowly decreased during the rest of both seasons. In 2007, when the field season was extended, $\mathrm{pH}$ decreased rapidly after mid-October. Lakewide daily median $\mathrm{pH}$ ranged from 7.3 on November 9 to 10.0 on July 2 in 2007 and 7.7 on May 31 to 9.8 on July 13 in 2008 . The steady pH throughout the 2007-08 seasons differed from the 2005 and 2006 seasons, in which there were strong seasonal minima associated with the rapid decline in the AFA bloom (Hoilman and others, 2008; Lindenberg and others, 2008).

The 2007 lakewide daily median specific conductance values first peaked on July 1, coincident with a peak in dissolved oxygen concentration and $\mathrm{pH}$, followed by a decrease through mid-July (fig. 2). Specific conductance then remained relatively stable until mid-October when a sharp increase began that continued until the end of the season. Lakewide specific conductance values for 2008 steadily increased through the season to a maximum in late September. Lakewide daily median specific conductance ranged between $103 \mu \mathrm{s} / \mathrm{cm}$ on May 18 to $123 \mu \mathrm{s} / \mathrm{cm}$ on November 9 in 2007, and 106 $\mu \mathrm{s} / \mathrm{cm}$ on May 8 to $120 \mu \mathrm{s} / \mathrm{cm}$ on September 29 in 2008. Specific conductance in 2007-08 differed from that in 2005-06 in that specific conductance in 2005-06 had distinct peaks corresponding to minima in dissolved oxygen concentration and $\mathrm{pH}$ values associated with a rapid decline in the AFA bloom. In 2007, a peak in specific conductance was associated with an early peak in dissolved oxygen around July 1 , which indicates a different relation between specific conductance and dissolved oxygen than was observed in the other years.

Lakewide daily median temperatures in both years began to increase during the beginning of June and peaked in July (fig. 2). These temperatures persisted until late August to early September, when a gradual decrease occurred. Lakewide daily median temperatures peaked at $23.4^{\circ} \mathrm{C}$ on July 11 and July 29 in 2007, and $22.8^{\circ} \mathrm{C}$ on August 17 in 2008. Overall temperature patterns remained the same during the 2007-08 seasons when compared to 2005-06 seasons.

In 2007-08, water-quality conditions monitored at the Agency Lake northern and southern sites (AGN and AGS, respectively) were similar to those in Klamath Lake (figs. 3 and 4). Dissolved oxygen concentration first peaked in mid-June 2007 and at the beginning of July in 2008. Concentrations were highly variable through the rest of the season, with the lowest levels occurring during July and August of 2007 and 2008. Dissolved oxygen concentration in Agency Lake during 2007 ranged from $1.6 \mathrm{mg} / \mathrm{L}$ on July 28 to $14.3 \mathrm{mg} / \mathrm{L}$ on June 20 at AGN, and $3.4 \mathrm{mg} / \mathrm{L}$ on August 25 to $14.0 \mathrm{mg} / \mathrm{L}$ on September 27 at AGS. Dissolved oxygen concentration during 2008 ranged from $1.9 \mathrm{mg} / \mathrm{L}$ on August 3 to $13.3 \mathrm{mg} / \mathrm{L}$ on July 10 at AGN, and $6.8 \mathrm{mg} / \mathrm{L}$ on August 21 to $13.1 \mathrm{mg} / \mathrm{L}$ on June 28 at AGS. 

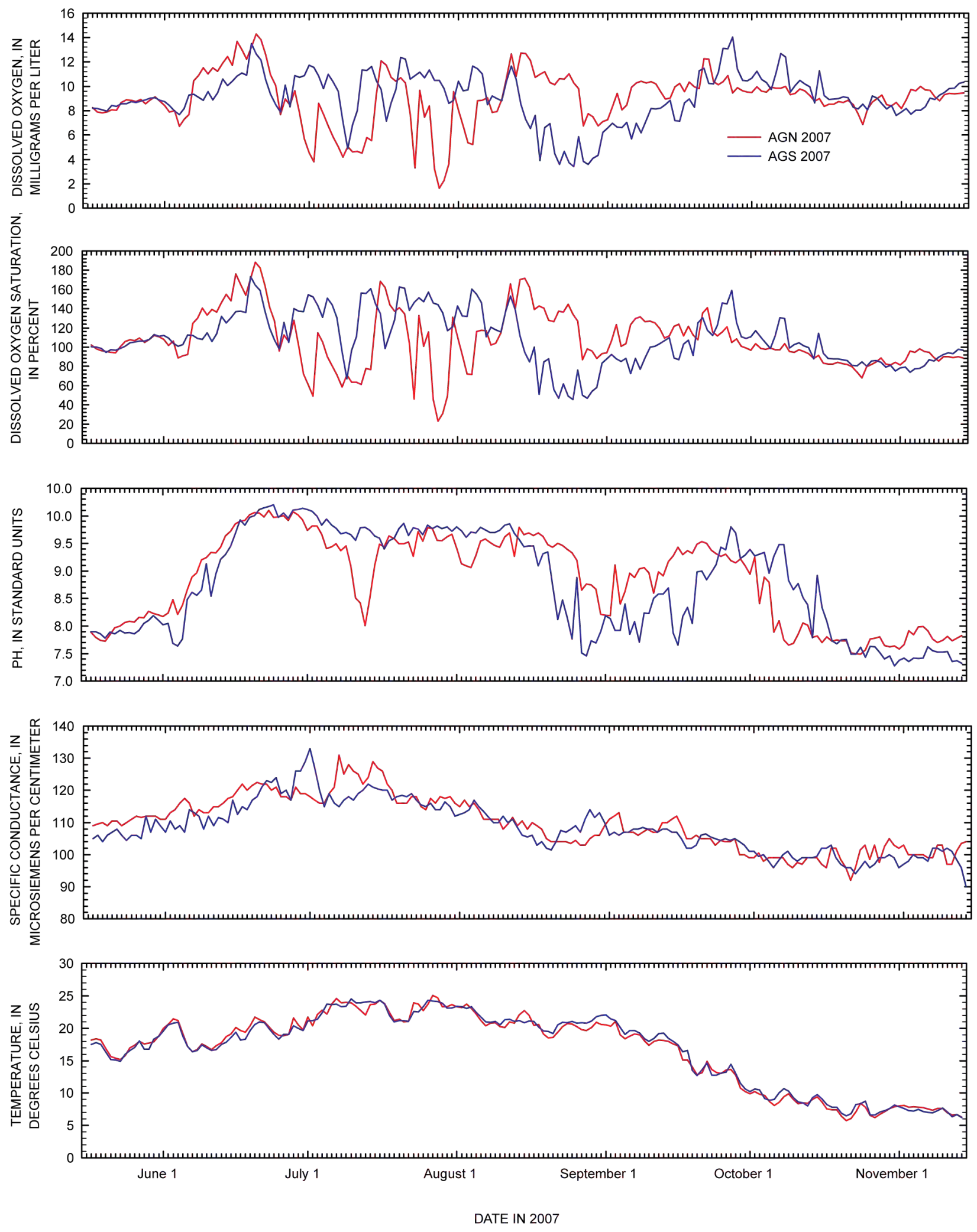

Figure 3. Dissolved oxygen concentration, dissolved oxygen percent saturation, pH, specific conductance, and temperature in Agency Lake, Oregon, 2007. 

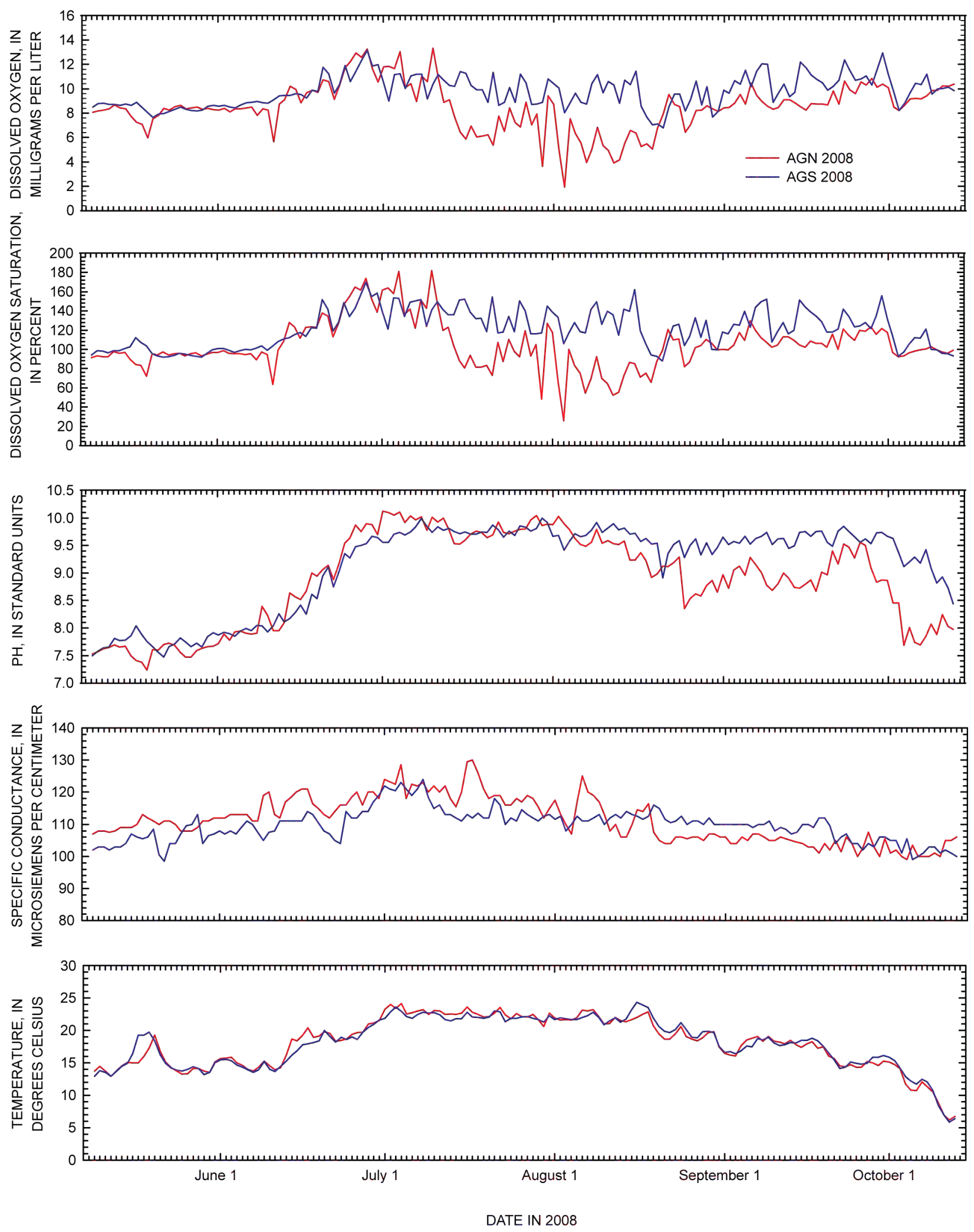

Figure 4. Dissolved oxygen concentration, dissolved oxygen percent saturation, $\mathrm{pH}$, specific conductance, and temperature in Agency Lake, Oregon, 2008. 
During 2007-08 at Agency Lake, pH rapidly increased in June, similar to pH in Upper Klamath Lake. A short, rapid decrease in pH occurred in 2007 in July at AGN before values at both stations decreased and became variable in late August. In 2008, pH remained high until decreasing in late September. Values in Agency Lake during 2007 ranged from 7.5 on October 24 to 10.1 on June 23 at AGN and 7.3 on October 31 to 10.2 on June 23 at AGS. Values during 2008 ranged from 7.2 on May 19 to 10.1 on July 1 at AGN and 7.5 on May 22 to 10.0 on July 30 at AGS.

Specific conductance peaked in early July 2007 and early to mid-July 2008 before a slow decrease for the rest of the season. Specific conductance in Agency Lake during 2007 ranged from 92 $\mu \mathrm{s} / \mathrm{cm}$ on October 21 to $131 \mu \mathrm{s} / \mathrm{cm}$ on July 7 at AGN, and $90 \mu \mathrm{s} / \mathrm{cm}$ on November 14 to $133 \mu \mathrm{s} / \mathrm{cm}$ on July 1 at AGS. Specific conductance during 2008 ranged from $99 \mu \mathrm{s} / \mathrm{cm}$ on October 4 to $130 \mu \mathrm{s} / \mathrm{cm}$ on July 17 at AGN, and $98 \mu \mathrm{s} / \mathrm{cm}$ on May 22 to $124 \mu \mathrm{s} / \mathrm{cm}$ on July 8 at AGS.

Water temperature increased in Agency Lake during June and remained high through August, decreasing in September 2007 and mid-August 2008. Water temperature in Agency Lake during 2007 ranged from $6.4^{\circ} \mathrm{C}$ on October 20 to $25.0^{\circ} \mathrm{C}$ on July 27 at AGN, and $6.2^{\circ} \mathrm{C}$ on November 14 to $23.4^{\circ} \mathrm{C}$ on July 9 at AGS. Water temperature during 2008 ranged from $6.2^{\circ} \mathrm{C}$ on October 12 to $23.4^{\circ} \mathrm{C}$ on July 3 at AGN, and $5.8^{\circ} \mathrm{C}$ on October 12 to $24.4^{\circ} \mathrm{C}$ on August 16 at AGS.

\section{Water-Quality Samples}

The detailed results from water-quality sampling are listed by station in appendix B. Total nitrogen and total phosphorus concentrations generally began to increase in mid-June in the 2007-08 seasons (figs. 5 and 6). Total nitrogen was variable and between about 1,200 and 5,800 $\mu \mathrm{g} / \mathrm{L}$ in both years through mid-October. In 2007, when the field season was extended, concentrations of both nutrients decreased between mid-October and mid-November. Concentrations often were highest at stations MDT and HDB and typically lowest at stations WMR, EPT, and RPT typically had lower concentrations. The peak total nitrogen concentrations by station in 2007 were $11,000 \mu \mathrm{g} / \mathrm{L}$ at HDB on September 11, 6,780 $\mu \mathrm{g} / \mathrm{L}$ at RPT on October 16, 5,800 $\mu \mathrm{g} / \mathrm{L}$ at MDT on July 9, and 5,670 $\mu \mathrm{g} / \mathrm{L}$ at MDN on August 8. The peak total nitrogen concentrations in 2008 were 5,670 $\mu \mathrm{g} / \mathrm{L}$ at MDT on August 4, 4,880 $\mu \mathrm{g} / \mathrm{L}$ at MDN on September 2, 3,400 $\mu \mathrm{g} / \mathrm{L}$ at EPT on August 11, and 2,710 $\mu \mathrm{g} / \mathrm{L}$ at WMR on July 14. The peak total phosphorus concentrations for 2007 by station were $810 \mu \mathrm{g} / \mathrm{L}$ at HDB on September 11, $470 \mu \mathrm{g} / \mathrm{L}$ at MDN on August 8, $420 \mu \mathrm{g} / \mathrm{L}$ at MDT on August 7, and $410 \mu \mathrm{g} / \mathrm{L}$ at EPT on August 8 and RPT on October 16. The peak total phosphorus concentrations for 2008 were $400 \mu \mathrm{g} / \mathrm{L}$ at MDT on August 4, $370 \mu \mathrm{g} / \mathrm{L}$ at MDN on September 2, $290 \mu \mathrm{g} / \mathrm{L}$ at EPT on August 11, and $240 \mu \mathrm{g} / \mathrm{L}$ at WMR on July 14. 

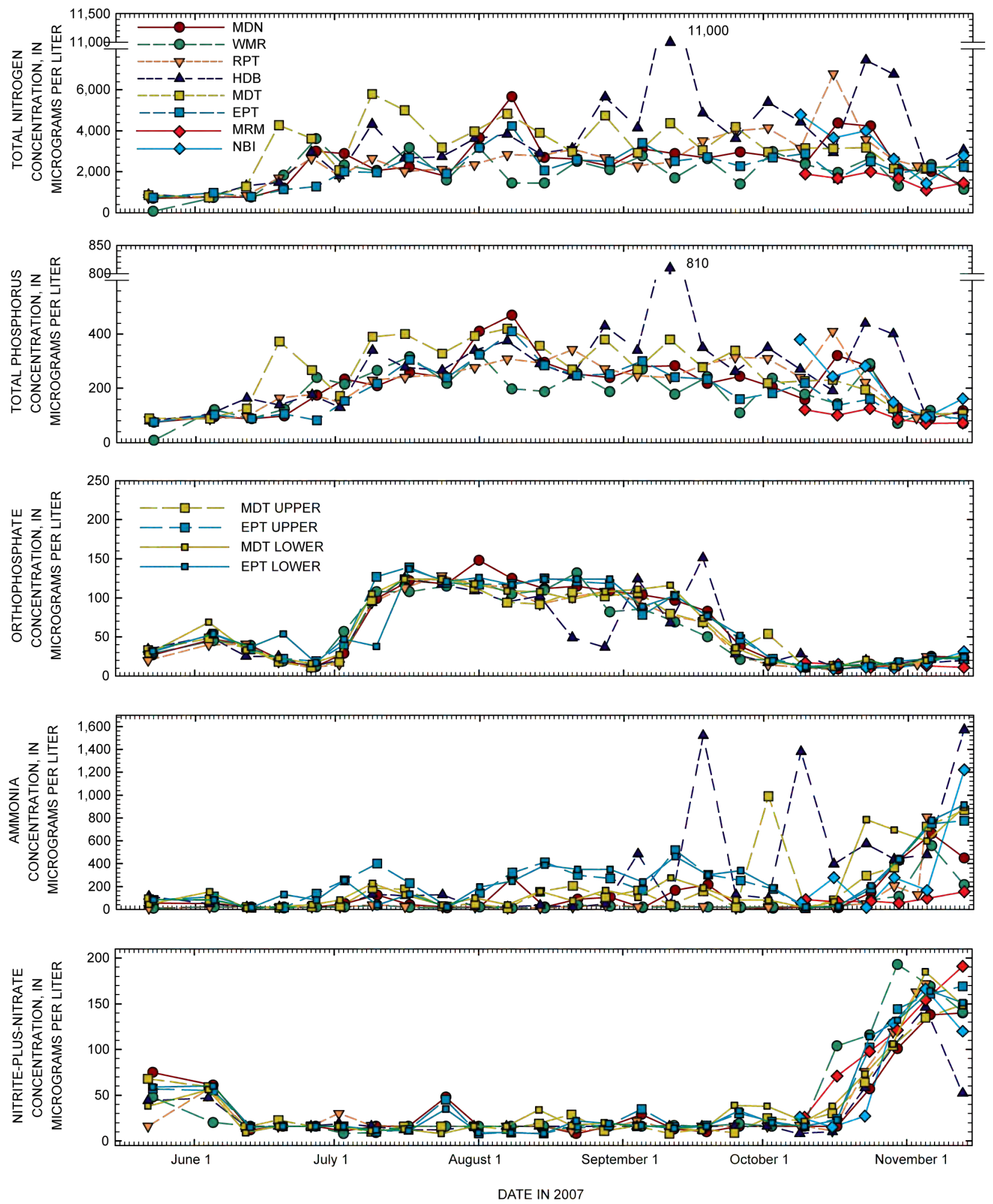

Figure 5. Total nitrogen, total phosphorus, orthophosphate, ammonia, and nitrite-plus-nitrate concentrations, Upper Klamath Lake, Oregon, 2007. Station descriptions are shown in table 1. 

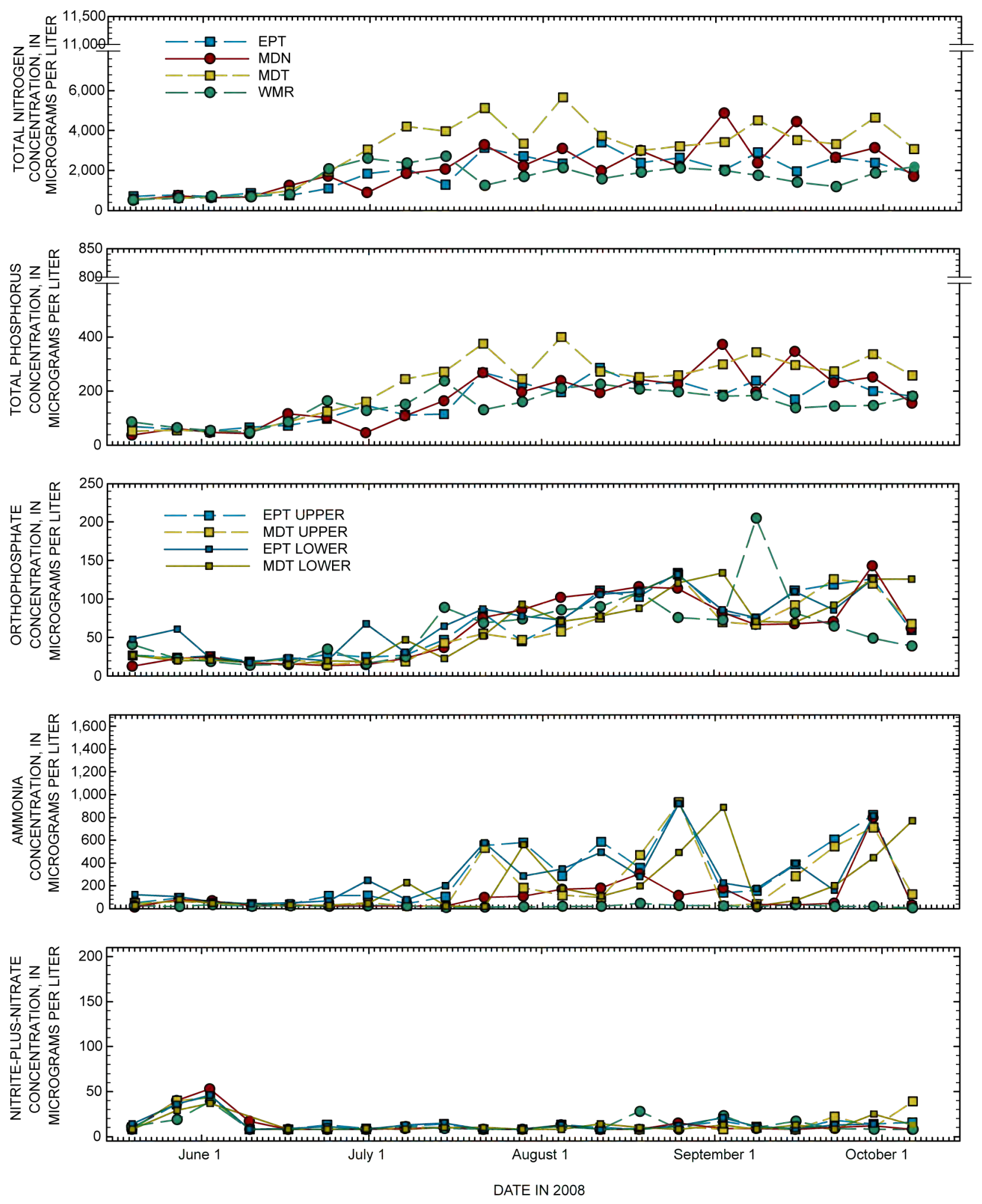

Figure 6. Total nitrogen, total phosphorus, orthophosphate, ammonia, and nitrite-plus-nitrate concentrations, Upper Klamath Lake, Oregon, 2008. Station descriptions are shown in table 1. 
In 2007, orthophosphate concentrations remained low until the beginning of July, when a rapid increase occurred. This increase was followed by steady concentrations of orthophosphate at most stations until a gradual decrease from the beginning of September through October. In 2008, orthophosphate concentrations began to increase at about the same time as they did in 2007, but much more slowly, leveling off in late August. The peak orthophosphate concentrations for 2007 by station were $151 \mu \mathrm{g} / \mathrm{L}$ at HDB on September 18, $148 \mu \mathrm{g} / \mathrm{L}$ at MDN on August 1, $139 \mu \mathrm{g} / \mathrm{L}$ at EPT on July 17, and $132 \mu \mathrm{g} / \mathrm{L}$ at WMR on August 22. The peak orthophosphate concentrations for 2008 were $205 \mu \mathrm{g} / \mathrm{L}$ at WMR on September 8, $143 \mu \mathrm{g} / \mathrm{L}$ at MDN on September 29, $134 \mu \mathrm{g} / \mathrm{L}$ at EPT on August 25, and 134 $\mu \mathrm{g} / \mathrm{L}$ at MDT on August 25.

In 2007-08, ammonia concentrations were at or near the detection limit at all stations during the second week in June, after which they began to increase. In 2007, ammonia concentrations were highest at station EPT through July and August, peaking at about $400 \mu \mathrm{g} / \mathrm{L}$, and lowest at stations WMR and RPT. A minimum in ammonia concentration at all stations in the third week of July 2007 coincided with a peak in nitrate-plus-nitrate, indicating that nitrification was occurring. A few large peaks in ammonia concentration occurred at stations HDB and MDT in September and October 2007, when concentrations at stations EPT and MDN generally were decreasing. During the extended season after mid-October 2008, ammonia concentrations increased at most stations. In 2008, ammonia concentrations at stations MDT and EPT reached nearly $600 \mu \mathrm{g} / \mathrm{L}$ in July and greater than $900 \mu \mathrm{g} / \mathrm{L}$ in August. Ammonia concentrations at station WMR were again the lowest for all stations (samples were not collected at station RPT). Concentrations at all stations except WMR increased between mid-September and the end of the field season. Ammonia concentrations were consistently low at stations WMR and RPT in 2007 and WMR in 2008. The peak concentrations for ammonia by station in 2007 were $1,570 \mu \mathrm{g} / \mathrm{L}$ at HDB on November 13, 1,220 $\mu \mathrm{g} / \mathrm{L}$ at NBI on November 13, $989 \mu \mathrm{g} / \mathrm{L}$ at MDT on October 2, and $914 \mu \mathrm{g} / \mathrm{L}$ at EPT on November 13. The peak concentrations for ammonia in 2008 were $935 \mu \mathrm{g} / \mathrm{L}$ at MDT on August 25, $933 \mu \mathrm{g} / \mathrm{L}$ at EPT on August 25, $800 \mu \mathrm{g} / \mathrm{L}$ at MDN on September 29, and $46 \mu \mathrm{g} / \mathrm{L}$ at WMR on August 18.

Nitrite plus nitrate concentrations first peaked in late May to early June in 2007-08, before decreasing to concentrations at or near the detection limit at most stations in mid-June. Concentrations remained low at most stations through much of the season with short-duration increases at different stations through September. In 2007, a large increase in nitrite plus nitrate occurred after mid-October during the extended field season. The peak nitrite plus nitrate concentrations by station for 2007 were $193 \mu \mathrm{g} / \mathrm{L}$ at WMR on October 30, $191 \mu \mathrm{g} / \mathrm{L}$ at MRM on November 13, $185 \mu \mathrm{g} / \mathrm{L}$ at MDT on November 5 , and $172 \mu \mathrm{g} / \mathrm{L}$ at RPT on November 13. The peak nitrite plus nitrate concentrations for 2008 were 53 $\mu \mathrm{g} / \mathrm{L}$ at MDN, $46 \mu \mathrm{g} / \mathrm{L}$ at EPT, $43 \mu \mathrm{g} / \mathrm{L}$ at MDT, and $39 \mu \mathrm{g} / \mathrm{L}$ at WMR, all on June 2.

In 2008, chlorophyll $a$ concentrations began to increase during early June, with the first peak occurring in early July (fig. 7). Concentrations remained high at many stations until mid-August before increasing again in late August to early September. Concentrations at stations WMR and EPT typically were less than $200 \mu \mathrm{g} / \mathrm{L}$; however, concentrations at stations MDT and MDN were often higher than concentrations at stations WMR and EPT. The peak chlorophyll $a$ concentrations by station for 2008 were $561 \mu \mathrm{g} / \mathrm{L}$ at MDT on August 4, $450 \mu \mathrm{g} / \mathrm{L}$ at MDN on September 15, $254 \mu \mathrm{g} / \mathrm{L}$ at WMR on June 30, and $153 \mu \mathrm{g} / \mathrm{L}$ at EPT on September 8. Chlorophyll $a$ data analyzed in 2007 were determined to be of poor quality based on quality-assurance data and are not reported. 


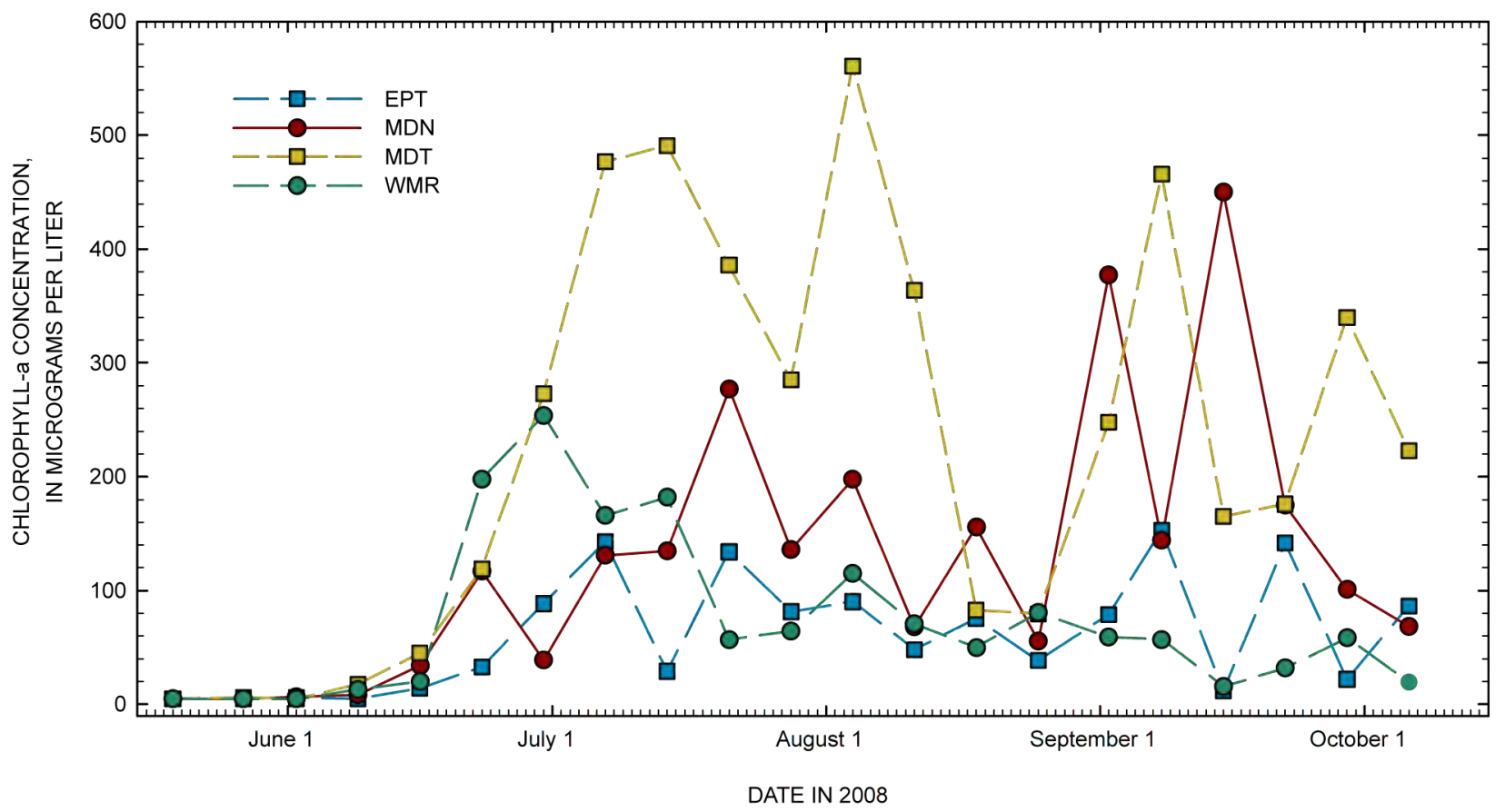

Figure 7. Chlorophyll a concentrations, Upper Klamath Lake, Oregon, 2008. Station descriptions are shown in table 1.

When high ammonia concentrations occur coincident with high $\mathrm{pH}$ and high temperatures, a significant fraction of the ammonia concentration is present in the un-ionized form, which is particularly toxic to aquatic life. The dependence on $\mathrm{pH}$ is stronger than the dependence on temperature; at $22^{\circ} \mathrm{C}$ and a pH of 9, for example, 31 percent of the ammonia will be in un-ionized form, but at a temperature of $22^{\circ} \mathrm{C}$ and a pH of 9.5, the fraction jumps to 59 percent (U.S. Environmental Protection Agency, 1998). Mean un-ionized ammonia concentrations that would have been lethal to suckers in 2007-08 (Saiki and others, 1999) ranged from 480 to $1,290 \mu \mathrm{g} / \mathrm{L}$. Concentrations of un-ionized ammonia measured in the Upper Klamath Lake in 2007-08 did not reach potentially lethal concentrations (figs. 8 and 9).

Un-ionized ammonia concentrations first began to increase in mid-June (figs. 8 and 9). Because un-ionized ammonia concentration increases not only with total ammonia concentration, but also with temperature and $\mathrm{pH}$, the highest concentrations occurred in July of both years, even though the highest total ammonia concentrations occurred later in both seasons. During 2007, stations HDB and MDT had peaks mid- to late season that did not coincide with the other locations. Un-ionized ammonia concentrations were consistently low at stations WMR and RPT in 2007 and WMR in 2008. The peak un-ionized ammonia concentrations by station for 2007 were $284 \mu \mathrm{g} / \mathrm{L}$ at MDT on October 2, $243 \mu \mathrm{g} / \mathrm{L}$ at EPT on July 10, $150 \mu \mathrm{g} / \mathrm{L}$ at HDB on September 4, and $114 \mu \mathrm{g} / \mathrm{L}$ at MDN on August 8. The peak unionized ammonia concentrations for 2008 were $271 \mu \mathrm{g} / \mathrm{L}$ at MDT on July 21, $256 \mu \mathrm{g} / \mathrm{L}$ at EPT on July 21, $134 \mu \mathrm{g} / \mathrm{L}$ MDN on August 18, and $25 \mu \mathrm{g} / \mathrm{L}$ at WMR on August 18. 


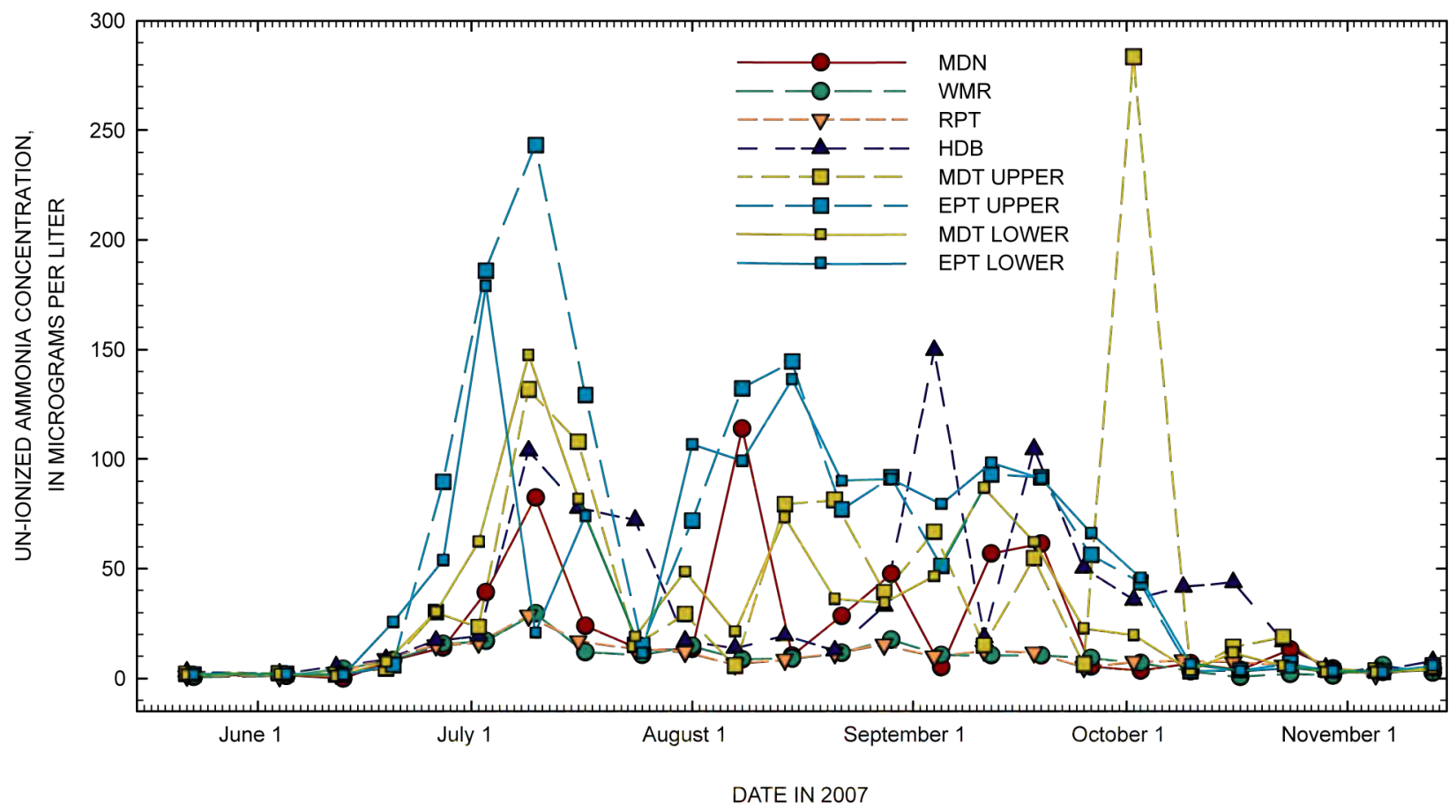

Figure 8. Un-ionized ammonia concentrations, Upper Klamath Lake, Oregon, 2007. Station descriptions are shown in table 1.

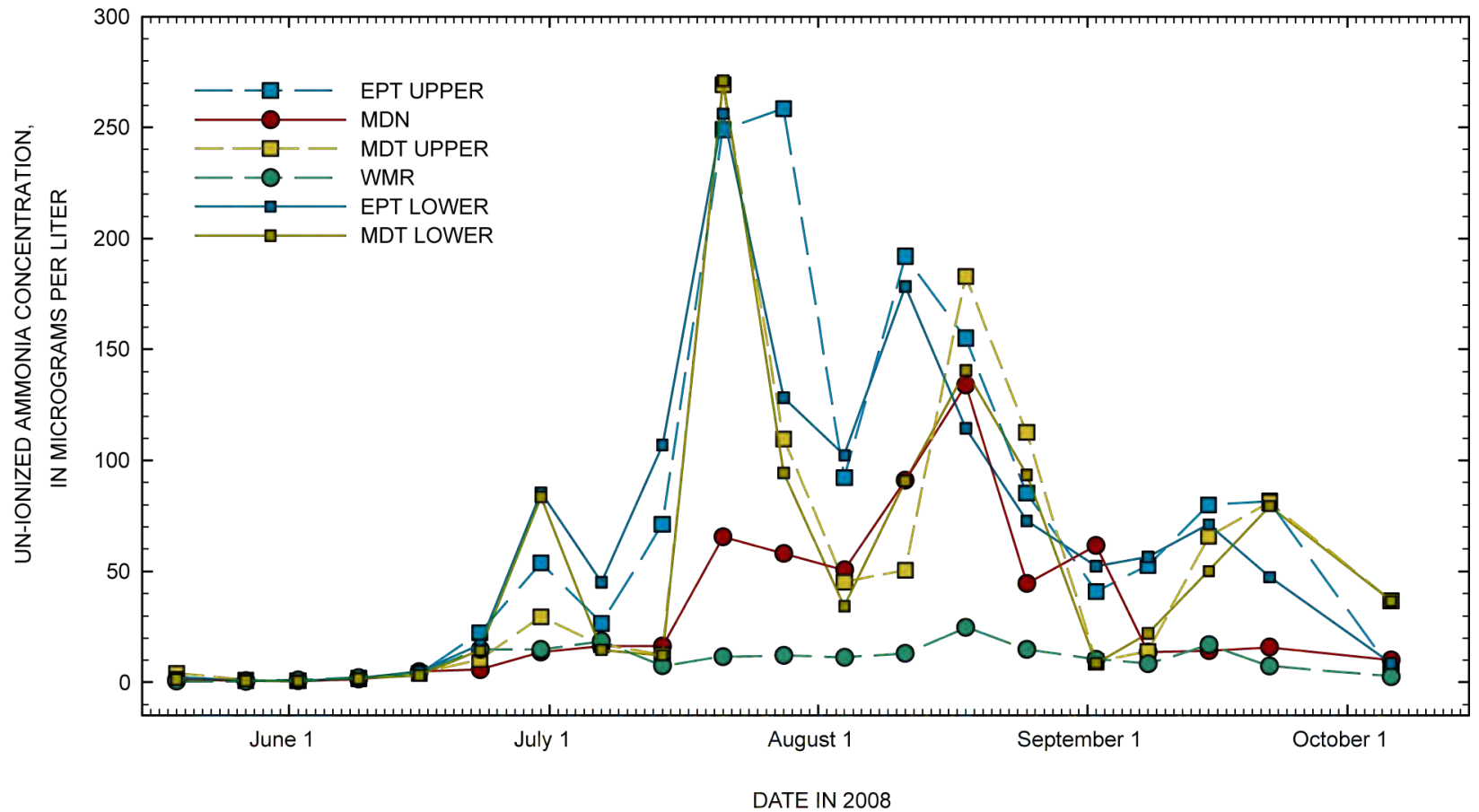

Figure 9. Un-ionized ammonia concentrations, Upper Klamath Lake, Oregon, 2008. Station descriptions are shown in table 1. 
Samples were collected for the analysis of dissolved organic carbon (DOC) late in the 2007 season in order to monitor this constituent for several weeks before and after the breaching of Williamson River Delta levees on October 30. In general, there was no evidence of an increase in DOC subsequent to the breaching of the levees. The concentration at most stations was greater on one of the sampling dates prior to October $30(8,600 \mu \mathrm{g} / \mathrm{L}$ at station HDB on October 9; 8,300 $\mu \mathrm{g} / \mathrm{L}$ at station MDT on October 10; 8,200 $\mu \mathrm{g} / \mathrm{L}$ at station NBI on October 16; and 8,100 $\mu \mathrm{g} / \mathrm{L}$ at station EPT on October 10) (fig. 10). The highest DOC concentration was measured at station WMR (the station closest to the Williamson River Delta) during the 6 weeks of data on the first sampling date after the breaching of the levees at 6,400 $\mu \mathrm{g} / \mathrm{L}$ on November 6. This indicates that there may have been some transfer of DOC from the newly inundated land in the Delta to the water column. By the second sampling date after the breaching of the levees, the DOC concentration at this station was similar to the concentration measured in the weeks prior to October 30.

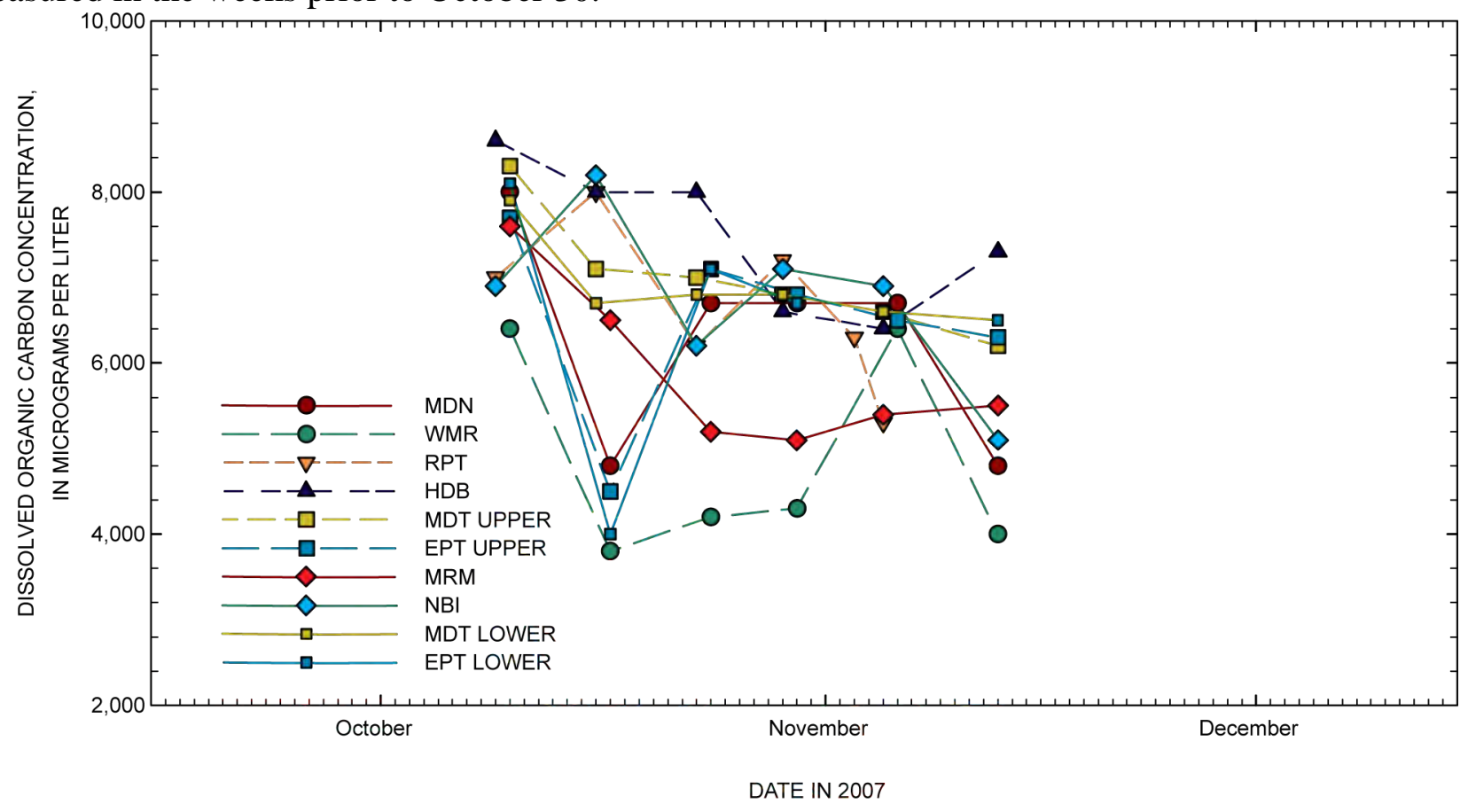

Figure 10. Dissolved organic carbon concentrations, Upper Klamath Lake, Oregon, 2007. Station descriptions are shown in table 1.

\section{Meteorological Data}

During the 2007-08 field seasons, the lakewide daily median air temperatures increased through the beginning of June until mid-July before decreasing in September (fig. 11). Daily median air temperature peaked at $24.5^{\circ} \mathrm{C}$ on July 5 in 2007 and at $25.1^{\circ} \mathrm{C}$ on August 16 in 2008 . Relative humidity remained low from June through August before increasing in September. Daily median relative humidity ranged from 44 percent on August 11 to 88 percent on October 18 in 2007 and 42 percent on July 12 to 86 percent on October 3 in 2008. The last week in May 2008 was particularly cold and humid compared to the same period in 2007. Solar radiation through the summer was relatively constant, reflecting the high percentage of cloud-free days in this area of Oregon, and started to trend downward in September as the days became shorter. Maximum daily median solar radiation during the both field 
seasons was about $577 \mathrm{~W} / \mathrm{m}^{2}$. Wind speed was variable during the first and last parts of the season and relatively calm between July and September. Maximum daily median wind speed during the 2007 field season was $7 \mathrm{~m} / \mathrm{s}$ on October 25 and $8 \mathrm{~m} / \mathrm{s}$ on October 11 in 2008. The highest winds were predominantly from the northwest at stations MDL, SSHR, HDB, and BLB and from the west at stations WME/WMR and MDN (figs. 12 and 13). At stations BLB and WME/WMR, a second prevailing wind direction characterized by lower wind speeds was apparent; these winds were from the north at BLB and from the northwest at WME/WMR.
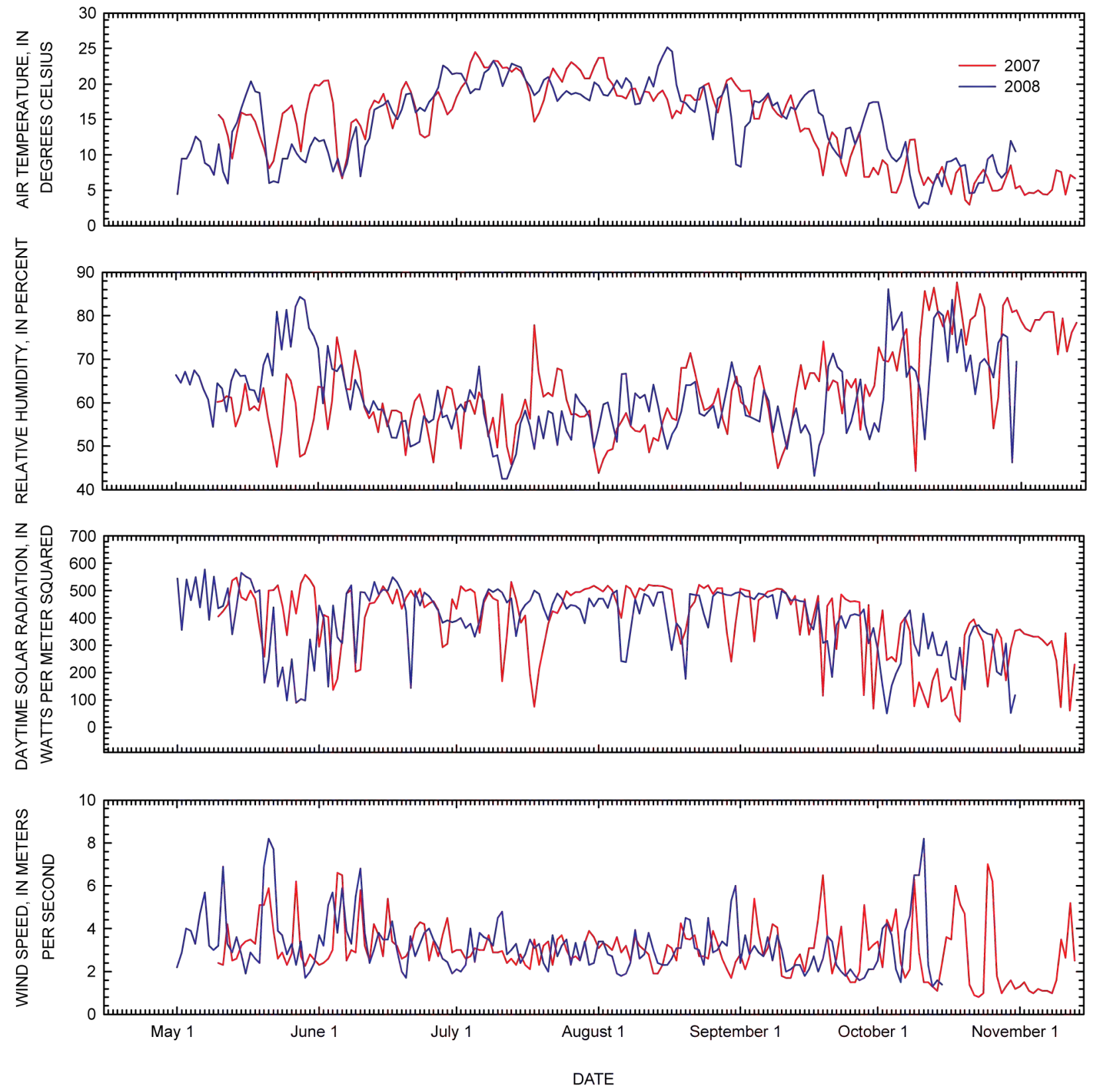

Figure 11. Lakewide daily median air temperature (number of stations $[n]=5)$, relative humidity $(n=5)$, daytime solar radiation $(n=2)$, and wind speed $(n=6)$, Upper Klamath Lake, Oregon, 2007-08. 

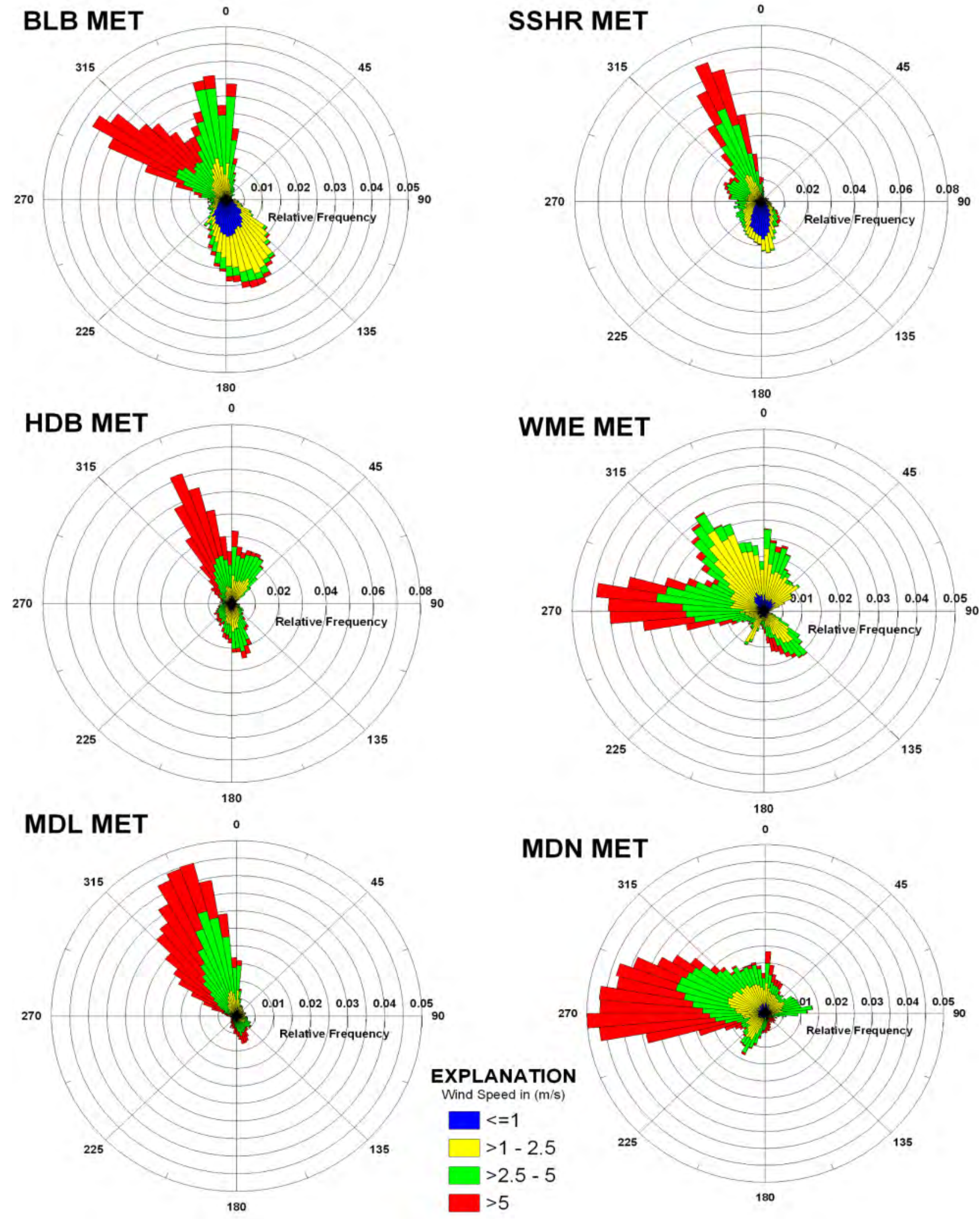
Figure 12. Wind speed and direction at meteorological stations near Upper Klamath Lake, Oregon, 2007. Station descriptions are shown in table 2.

Figure 13. Wind speed and direction at meteorological stations near Upper Klamath Lake, Oregon, 2008. Station descriptions are shown in table 2.

\section{Acknowledgments}

The assistance of Scott Vanderkooi and many personnel of the USGS Klamath Falls Field Station is gratefully acknowledged for facilitating the water-quality field program with the use of boats, trucks, field equipment, and office and laboratory facilities. Many people contributed to the field work of this study, and their efforts are gratefully acknowledged: Matthew Abel, William Ayers, Elena Ceballos, Amari Dolan-Caret, Albert Simons, Dean Snyder, and William Wright. The efforts of Amy Brooks and Matt Johnston from the USGS Oregon Water Science Center in processing and checking the continuous datasets were critical to the success of the monitoring program.

\section{References Cited}

Banish, N.P., Adams, B.J., Shively, R.S., Mazur, M.M., Beauchamp, D.A., and Wood, T.M., 2009, Distribution and habitat associations of radio-tagged adult Lost River and shortnose suckers in Upper Klamath Lake, Oregon: Bethesda, Maryland, Transactions of the American Fisheries Society, v. 138, p. 153-168.

Bureau of Reclamation, 2000, Klamath project-Historical operation: Klamath Falls, Oregon, Bureau of Reclamation, 53 p. plus appendixes, accessed December 21, 2009, at http://www.usbr.gov/mp/kbao/docs/Historic\%20Operation.pdf.

Erdman, C.S., and Hendrixson, H.A., 2009, Larval shortnose and Lost River sucker response to large scale wetland restoration of the north half of the Williamson River Delta Preserve, Oregon: The Nature Conservancy, DOI 10.3411/col.07291948, accessed December 21, 2009, at http://conserveonline.org/library/larval-lost-river-and-shortnose-sucker-response-to/view.html.

Friedman, L.C., and Erdmann, D.E., 1982, Quality assurance practices for the chemical and biological analyses of water and fluvial sediment: U.S. Geological Survey Techniques of Water-Resources Investigations, book 5, chap. A6, 181 p., http//:pubs.usgs.gov/twri/twri5a6/.

Gartner, J.W., Wellman, R.E., Wood, T.M., and Cheng, R.T., 2007, Water velocity and suspended solids measurements by in-situ instruments in Upper Klamath Lake, Oregon: U.S. Geological Survey Open-File Report 2007-1279, 36 p., http//:pubs.usgs.gov/of/2007/1279/.

Hoilman, G.R., Lindenberg, M.K., and Wood, T.M., 2008, Water quality conditions in Upper Klamath and Agency Lakes, Oregon, 2005: U.S. Geological Survey Scientific Investigations Report 20085026, 44 p, http://pubs.usgs.gov/sir/2008/5026/.

Hubbard, L.L., 1970, Water budget of upper Klamath Lake, southwestern Oregon: U.S. Geological Survey Hydrologic Atlas 351, 1 plate.

Johnson, D.M., 1985, Atlas of Oregon lakes: Corvallis, Oregon, Oregon State University Press, 317 p.

Jones, B.E., 1987, Quality control manual of the U.S. Geological Survey’s National Water Quality Laboratory: U.S. Geological Survey Open-File Report 87-457, 17 p. 
Kann, Jacob, 1997, Ecology and water quality dynamics of a shallow hypereutrophic lake dominated by cyanobacteria (Aphanizomenon flos-aquae): Chapel Hill, University of North Carolina, Master's thesis, $110 \mathrm{p}$.

Kann, Jacob, 2007, Upper Klamath Lake 2006 data summary report, prepared for the Klamath Tribes Natural Resources Department: Chiloquin, Oregon, 28 p.

Lindenberg, M.K., Hoilman, Gene, and Wood, T.M., 2008, Water quality conditions in Upper Klamath and Agency Lakes, Oregon, 2006: U.S. Geological Survey Scientific Investigations Report 20085201, 54 p., http://pubs.usgs.gov/sir/2008/5201/.

Maloney, T.J., ed., 2005, Quality management system, U.S. Geological Survey National Water Quality Laboratory: U.S. Geological Survey Open-File Report 2005-1263, version 1.3, November 9, 2005, chapters and appendices [variously paged], http//:pubs.usgs.gov/0f/2005/1263/

Morace, J.L., 2007, Relation between selected water-quality variables, climatic factors, and lake levels in Upper Klamath and Agency Lakes, Oregon, 1990-2006: U.S. Geological Survey Scientific Investigations Report 2007-5117, 54 p., http://pubs.usgs.gov/sir/2007/5117/

Perkins, D., Kann, J., and Scoppettone, G.G., 2000, The role of poor water quality and fish kills in the decline of endangered Lost River and shortnose suckers in Upper Klamath Lake: U.S. Geological Survey, Biological Resources Division report submitted to Bureau of Reclamation, Klamath Falls Project Office, Klamath Falls, Oregon, Contract 4-AA-29-12160.

Pritt, J.W., and Raese, J.W., eds., 1995, Quality assurance/quality control manual-National Water Quality Laboratory: U.S. Geological Survey Open-File Report 95-443, 35 p.

Saiki, M.K., Monda, D.P., and Bellerud, B.L., 1999, Lethal levels of selected water quality variables to larval and juvenile Lost River and shortnose suckers: Environmental Pollution, v 105, p. 37-44.

Stubbs, K., and White, R., 1993, Lost River (Deltistes luxatus) and shortnose (Chasmistes brevirostris) sucker recovery plan: Portland, Oregon, U.S. Fish and Wildlife Service, 108 p.

U.S. Environmental Protection Agency, 1998, Update of ambient water quality criteria for ammonia: U.S. Environmental Protection Agency Office of Water, EPA 822-R-98-008.

U.S. Geological Survey, 2007, NWQL National Field Supply Service Quality Assurance Surveillance Plan (NFSS QASP): Denver, Colorado, U.S. Geological Survey National Water Quality Laboratory, $31 \mathrm{p}$.

U.S. Geological Survey, variously dated, National field manual for the collection of water-quality data: U.S. Geological Survey Techniques of Water-Resources Investigations, book 9, chaps. A1-A5, http://pubs.water.usgs.gov/twri9A/.

Wagner, R.J., Boulger, R.W., Jr., Oblinger, C.J., and Smith, B.A., 2006, Guidelines and standard procedures for continuous water-quality monitors: station operation, record computation, and data reporting: U.S. Geological Survey Techniques and Methods 1-D3, 51 p. plus attachments, http://pubs.usgs.gov/tm/2006/tm1D3/.

Wood, T.M., Hoilman, G.R., and Lindenberg, M.K., 2006, Water quality conditions in Upper Klamath Lake, Oregon, 2002-2004: U.S. Geological Survey Scientific Investigations Report 2006-5209, 52 p., http://pubs.usgs.gov/sir/2006/5209/ 
Wood, T.M., Cheng, R.T., Gartner, J.W., Hoilman, G.R., Lindenberg, M.K., and Wellman, R.E., 2008, Modeling hydrodynamics and heat transport in Upper Klamath Lake, Oregon, and implications for water quality: U.S. Geological Survey Scientific Investigations Report 2008-5076, 48 p, http://pubs.usgs.gov/sir/2008/5076/. 


\section{Appendix A. Quality-Control and Quality-Assurance Data for Water-Quality Samples}

The appendix tables are separate Excel files that can be downloaded by clicking on the table titles below.

Table A1. Quality-control and quality-assurance data for water-quality samples in Upper Klamath Lake, Oregon, 2007.

Table A2. Quality-control and quality-assurance data for water-quality samples in Upper Klamath Lake, Oregon, 2008.

\section{Appendix B. Data from Water-Quality Samples}

Table B1. Data from water-quality samples, Upper Klamath Lake, Oregon, 2007.

Table B2. Data from water-quality samples, Upper Klamath Lake, Oregon, 2008. 


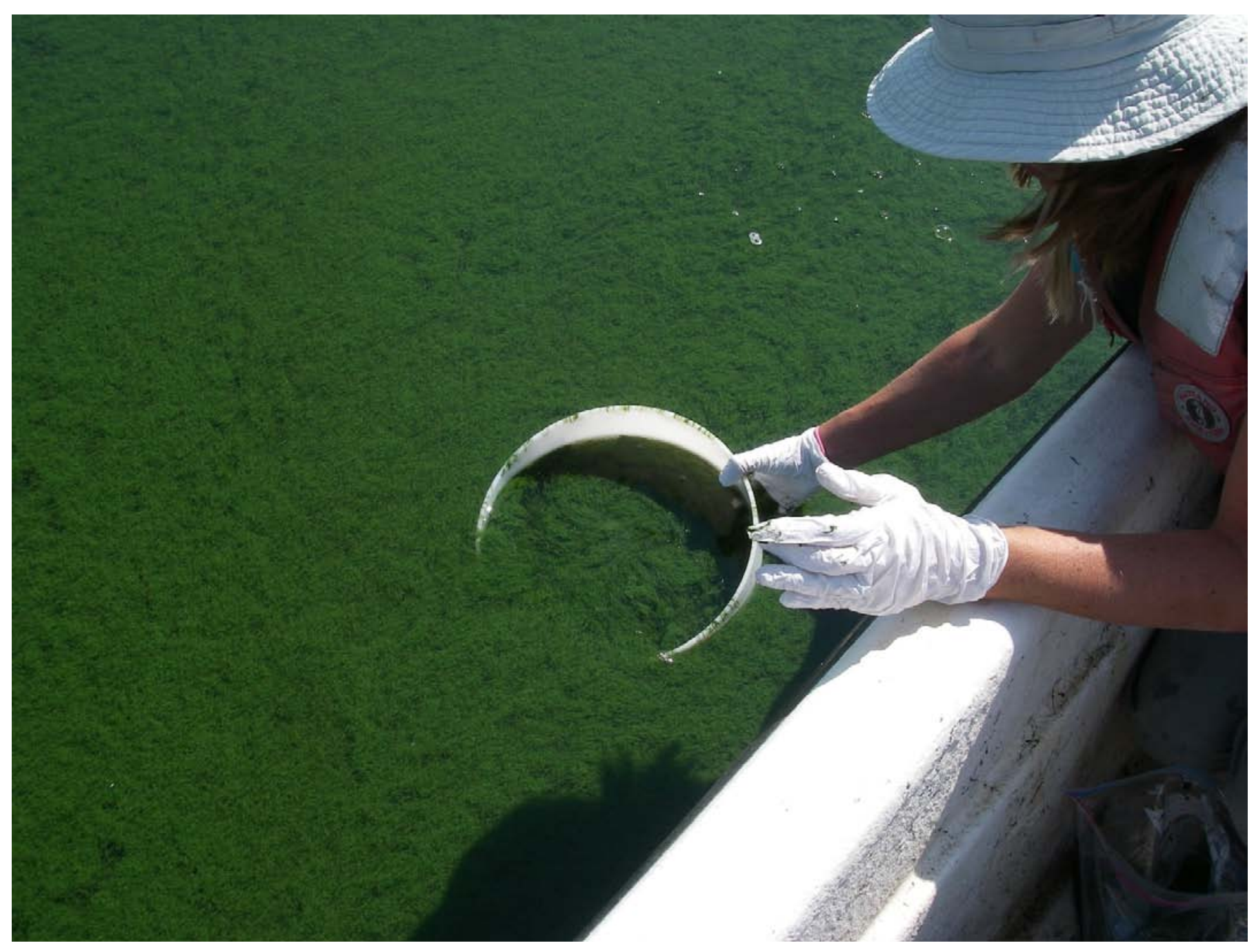

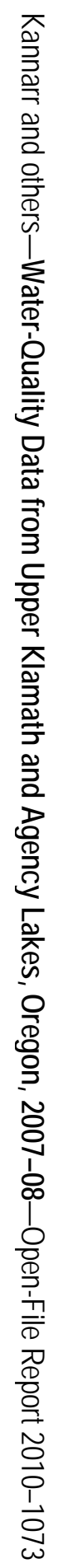

